\title{
Characterizing Thunderstorm Gust Fronts near Complex Terrain
}

\author{
NiCHOLAS T. LUCHETTI AND KATJA FRIEDRICH \\ Department of Atmospheric and Oceanic Sciences, University of Colorado Boulder, Boulder, Colorado \\ CHRISTOPHER E. RODELL \\ Department of Earth, Ocean, and Atmospheric Sciences, The University of British Columbia, \\ Vancouver, British Columbia, Canada \\ JULIE K. LUNDQUIST \\ Department of Atmospheric and Oceanic Sciences, University of Colorado Boulder, Boulder, and \\ National Renewable Energy Laboratory, Golden, Colorado
}

(Manuscript received 25 September 2019, in final form 18 May 2020)

\begin{abstract}
Fire safety, aviation, wind energy, and structural-engineering operations are impacted by thunderstorm outflow boundaries or gust fronts (GFs) particularly when they occur in mountainous terrain. For example, during the 2013 Arizona Yarnell Hill Fire, 19 firefighters were killed as a result of sudden changes in fire behavior triggered by a passing GF. Knowledge of GF behavior in complex terrain also determines departure and landing operations at nearby airports, and GFs can induce exceptional structural loads on wind turbines. While most examinations of GF characteristics focus on well-organized convection in areas such as the Great Plains, here the investigation is broadened to explore GF characteristics that evolve near the complex terrain of the Colorado Rocky Mountains. Using in situ observations from meteorological towers, as well as data from wind-profiling lidars and a microwave radiometer, $24 \mathrm{GF}$ events are assessed to quantify changes in wind, temperature, humidity, and turbulence in the lowest $300 \mathrm{~m}$ AGL as these GFs passed over the instruments. The changes in magnitude for all variables are on average weaker in the Colorado Front Range than those typically observed from organized, severe storms in flatter regions. Most events from this study experience an increase in wind speed from 1 to $8 \mathrm{~m} \mathrm{~s}^{-1}$, relative humidity from $1 \%$ to $8 \%$, and weak vertical motion from 0.3 to $3.6 \mathrm{~m} \mathrm{~s}^{-1}$ during GF passage while temperature drops by $0.2^{\circ}-3^{\circ} \mathrm{C}$ and turbulent kinetic energy peaks at $>4 \mathrm{~m}^{2} \mathrm{~s}^{-2}$. Vertical profiles reveal that these changes vary little with height in the lowest $300 \mathrm{~m}$.
\end{abstract}

\section{Introduction}

Forecasting and monitoring the potential for severe wind damage associated with thunderstorm outflow boundaries or gust fronts (GFs) are important for structural and personal safety across a variety of sectors such as aviation, structural engineering, wind energy, the wildland fire community, and the emergency response community. A GF is the leading edge of cold air propagating horizontally away from a thunderstorm (Simpson 1969; Droegemeier and Wilhelmson 1987). The pool of cold air results from the evaporation of liquid water and the

Corresponding author: Nicholas Luchetti, nicholas.luchetti@ colorado.edu melting and sublimation of frozen hydrometers (e.g., hail or graupel) in the thunderstorm downdraft. Despite increased interest in understanding the evolution of GFs, few observations exist of GF effects on atmospheric properties (wind, temperature, humidity, turbulence) in mountainous terrain because of the limitation and sparsity of weather observations. Most observational GF studies focus on orographically flat regions such as the U.S. Great Plains (e.g., Charba 1974; Craig Goff 1976; Engerer et al. 2008; Bryan and Parker 2010). These studies mainly analyze GFs from organized thunderstorms such as supercell thunderstorms, squall lines, or mesoscale convective systems (MCSs). In and near complex terrain, however, thunderstorms are usually less organized as single cell and multicell thunderstorms 
(Bunkers et al. 2006; Keighton et al. 2007; Parker and Ahijevych 2007; Schneider 2009; Ashley et al. 2019). In this study, we analyze the changes in atmospheric properties of 24 GFs observed with remote sensing and in situ instruments in the Colorado Front Range with the goal of identifying and comparing atmospheric properties of GFs near complex terrain with those observed in flat terrain.

GFs can be associated with strong turbulence and rapid wind increase and shear creating potential dangers to humans and structures. During the 2013 Yarnell Hill Fire in Arizona, for example, 19 firefighters were killed because of rapid and severe changes to the fire's behavior, driven by a GF moving over the fire (Hardy and Comfort 2015; Paez et al. 2015). Tragic events such as this one give incentive to the wildland fire community and emergency responders to better understand the evolution of GFs in areas of complex terrain (Joint Fire Science Program 2017). Similarly, GFs can exert loads on structures such as buildings and wind turbines, motivating attention from the structural-engineering community (Chay et al. 2006; Kwon and Kareem 2009; Lombardo et al. 2014, 2018; Solari et al. 2015). Vertical wind shear and turbulence can directly impact the productivity of a wind turbine and influence the lifetime of its rotor blades and other components (Manwell et al. 2002; International Electrotechnical Commission 2005; Nguyen et al. 2011; Lu et al. 2019). Wind turbine design engineers are, therefore, concerned with potential structural damage from interactions with strong GFs (Letchford et al. 2002; Solari 2014; Lombardo et al. 2018). The duration of the peak wind gusts and turbulence associated with GF passage also has a critical role in the response of structures to wind loading (Kwon and Kareem 2009; Lombardo et al. 2018; Zhang et al. 2018). Engineers must understand both the intensity of wind speeds associated with GFs as well as the duration over which structures are exposed to peak gusts and turbulence.

GFs often behave like density or gravity currents (Benjamin 1968; Charba 1974; Sasaki and Baxter 1986; Friedrich et al. 2005; Bryan and Rotunno 2008). On their leading edge, a noselike shape forms that tends to be deeper and marks the region where the strongest lift and convergence between the outflow and environmental air occurs. GFs are typically on the order of $0.5-2 \mathrm{~km}$ deep; however, this depth can range between $100 \mathrm{~m}$ and $4 \mathrm{~km}$, depending on the strength and distance from the downdraft source (Cotton et al. 2011). For example, GF depth associated with MCSs have been observed to be greater than 4 km (Bryan 2005; Bryan and Parker 2010). As a GF passes over a meteorological weather station, observations typically report an abrupt change in wind direction and speed, a decrease in temperature, and an increase in humidity (Simpson 1969; Charba 1974; Craig Goff 1976; Fujita 1981; Droegemeier and Wilhelmson 1987; Lompar et al. 2018). The intensity of such changes is proportional to the strength and depth of the passing GF. Few observational studies on GF behavior in mountainous or nearmountainous terrain exist (Mahoney 1988; Bidokhti and Bani-Hashem 2001; Kishcha et al. 2016). Most of these GFs originated from thunderstorms that are less organized compared to GFs from MCSs or supercell thunderstorms often studied in the U.S. Great Plains. The lack of organization in mountainous or near-mountainous thunderstorms can be linked to reduced temperatures, low-level moisture, and surface-based instability compared to lower elevations (Bunkers et al. 2006; Keighton et al. 2007; Schneider 2009). However, given the increase in high-impact wind-driven wildfire events in recent years, there is a need to study GFs from less-organized thunderstorms that initiate in areas of complex or near-complex terrain.

Motivated by the need to better comprehend GF characteristics in and near mountainous terrain, this study quantifies the duration and magnitude of shifts in temperature, wind, turbulence, and moisture associated with GFs and how these characteristics vary with height in the lowest $300 \mathrm{~m}$ above ground level (AGL). Section 2 discusses the datasets used, including location, instrumentation, and local physiography for each of the two study sites. Section 3 discusses methods emphasizing the detection, quantification, and statistical techniques used to assess GFs in this study. Results are presented in section 4. Discussion of the results and how they compare to GFs observed in flat terrain is found in section 5 . Conclusions and suggestions for future work are discussed in section 6 .

\section{Study sites and instruments}

\section{a. Colorado study site descriptions}

Data from two field campaigns conducted along the Colorado Front Range (Fig. 1) are used for this analysis. The first dataset consists of measurements from in situ and remote sensing instruments that were deployed during the Experimental Planetary Boundary Layer Instrument Assessment (XPIA) campaign (Lundquist et al. 2017; https://a2e.energy.gov/projects/xpia), which took place from 1 May to 30 June 2015. The XPIA campaign was located at the Boulder Atmospheric Observatory (BAO; Fig. 1). The BAO (Kaimal and Gaynor 1983; Wolfe and Lataitis 2018) is located about $25 \mathrm{~km}$ east of the eastern slopes of the Rocky Mountains and $25 \mathrm{~km}$ north of downtown Denver, Colorado, at an elevation of $1584 \mathrm{~m}$ above mean sea level (MSL). The second dataset consists of measurements from an instrument comparison campaign 


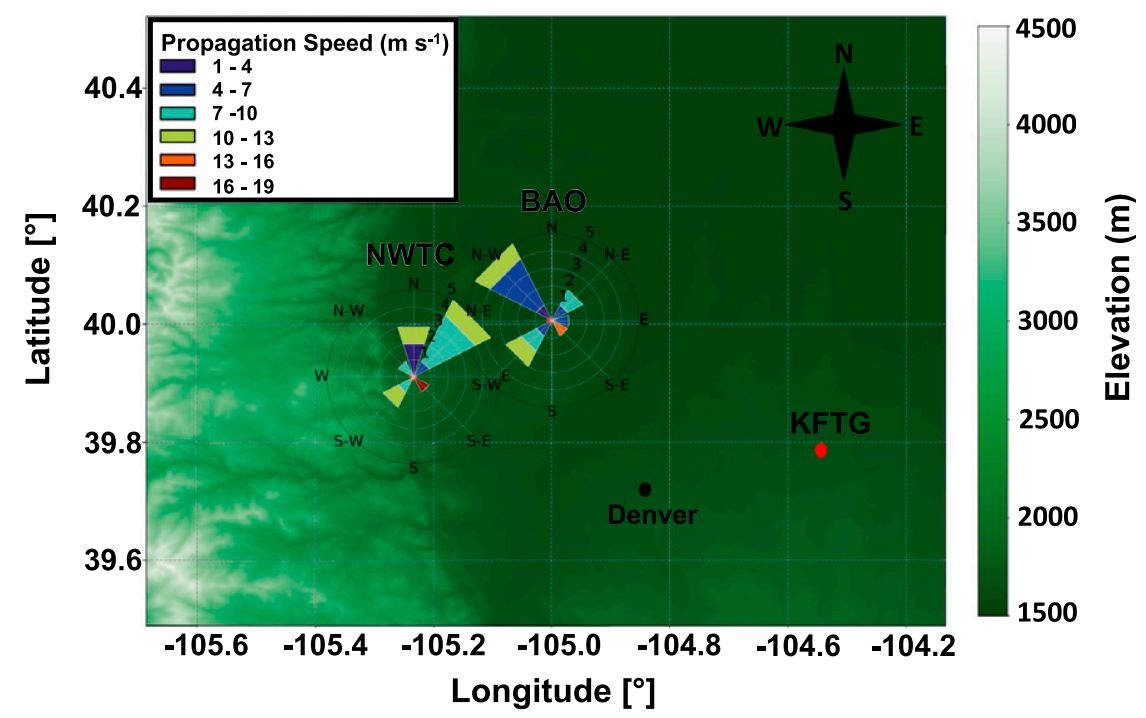

FIG. 1. Topographic map showing the Colorado Front Range study site locations: BAO and NWTC. The location of the NWS Denver (KFTG) NEXRAD site is shown as a filled red circle. Rose diagrams at each site indicate the number of gust fronts (range values), the direction from which the GFs propagated, and their propagation speeds $\left(\mathrm{m} \mathrm{s}^{-1}\right.$; color coded $)$.

conducted at the National Wind Technology Center (NWTC) at the National Renewable Energy Laboratory (Fig. 1), also along the Colorado Front Range. Covered mostly by short grass, the NWTC is located about $4 \mathrm{~km}$ east of the eastern slopes of the Rocky Mountains and $20 \mathrm{~km}$ northwest of Denver and is situated at $1852 \mathrm{~m}$ MSL (Clifton and Lundquist 2012; Clifton et al. 2013; Aitken et al. 2014). Some instruments only operated for a limited time between 1 May and 31 August 2012, 1 June and 30 June 2013, and 1 May and 30 June 2014. Both sites are located on slightly elevated hills and are frequently influenced by terrain-channeled drainage flow, downsloping katabatic winds, or general terrain-induced diurnal circulations from the nearby Colorado Front Range mountains (Banta et al. 1993; Clifton and Lundquist 2012). Thunderstorms that develop near these sites also tend to be weaker and less organized until they propagate into far eastern Colorado where the terrain is less rugged and organization is more favorable (Cotton et al. 1983; McAnelly and Cotton 1986; Tucker and Crook 1999).

\section{b. Description of in situ research instruments}

In situ observations from one meteorological tower at the BAO and two towers at the NWTC are used in this study (Table 1). The 300-m BAO tower provides wind, temperature, and relative humidity measurements at 2, 10, 100, and $300 \mathrm{~m}$ AGL every $1 \mathrm{~min}$ (Kaimal and Gaynor 1983; Wolfe and Lataitis 2018). Vaisala HMP temperature and relative humidity probes have accuracies of $\pm 0.1^{\circ} \mathrm{C}$ and $\pm 0.8 \%$. Horizontal wind is measured every $2 \mathrm{~s}$ at 10 and $100 \mathrm{~m}$ AGL using prop vane anemometers and at $300 \mathrm{~m}$ using a 2D sonic anemometer with accuracies of $\pm 0.1 \mathrm{~m} \mathrm{~s}^{-1}$ for wind speed and $\pm 1^{\circ}$ for wind direction. In addition, two $3 \mathrm{D}$ sonic anemometers (Campbell CSAT3) providing vertical and horizontal wind and six Sensiron SHT75 solid-state temperature/relative humidity sensors were also deployed at six levels (for measurement heights and accuracy, see Table 1). Anemometers are deployed on two boom arms, pointing at $334^{\circ}$ and $154^{\circ}$ from north, respectively. Inaccuracies and biases in wind and turbulence measurements are introduced when the tower structure is in the wake of the ambient flow (McCaffrey et al. 2017). To avoid impacts from the tower on wind measurements, we only consider winds between $25^{\circ}$ and $100^{\circ}$ and $175^{\circ}$ and $300^{\circ}$ following McCaffrey et al. (2017), which reduces the wind analysis by four events.

Wind observations from all anemometers are used to derive turbulence intensity (TI); TI is the ratio of the standard deviation of the horizontal wind speed $\left(\sigma_{v} ; \mathrm{m} \mathrm{s}^{-1}\right)$ and the mean horizontal wind speed $\left(\bar{V} ; \mathrm{m} \mathrm{s}^{-1}\right)$, both averaged over $2 \mathrm{~min}$ :

$$
\mathrm{TI}=\sigma_{v} / \bar{V}
$$

In this study, we will discuss maximum and mean TI during the time of GF passage. The 3D wind field from the sonic anemometers is also used to assess the turbulence kinetic energy (TKE): 
TABLE 1. Research instruments deployed along the Colorado Front Range and their instrument specifics. The first four rows highlight the tower and in situ instruments. The bottom three rows highlight the remote sensing instruments.

\begin{tabular}{|c|c|c|c|c|}
\hline Instrument/facility & $\begin{array}{l}\text { Output } \\
\text { frequency } \\
\quad(\min )\end{array}$ & $\begin{array}{c}\text { Measurement } \\
\text { heights }(\mathrm{m}) \mathrm{AGL}\end{array}$ & Variables measured/derived & Accuracy \\
\hline BAO 300-m meteorological tower-XPIA & 1 & $2,10,100$, and 300 & $\begin{array}{l}u \text { and } v \text { component of wind, } \\
\text { turbulence intensity, } \\
\text { temperature, and relative } \\
\text { humidity }\end{array}$ & $\begin{array}{l}\text { Temperature: } \pm 0.1^{\circ} \mathrm{C} \\
\text { relative humidity: } 0.8 \% \\
\text { wind speed: } \pm 0.1 \mathrm{~m} \mathrm{~s}^{-1} \\
\text { and wind direction: } \pm 1^{\circ}\end{array}$ \\
\hline $\begin{array}{l}\text { BAO additional instruments (Campbell } \\
\text { CSAT3 3D sonic anemometers; } \\
\text { Sensiron SHT75 solid-state temperature } \\
\text { and humidity probes)_XPIA }\end{array}$ & 1 & $\begin{array}{l}50,100,150,200 \\
250, \text { and } 300\end{array}$ & $\begin{array}{l}u, v, \text { and } w \text { component of } \\
\text { wind, turbulence intensity, } \\
\text { turbulent kinetic energy, } \\
\text { temperature, and relative } \\
\text { humidity }\end{array}$ & $\begin{array}{l}\text { Temperature: } \pm 0.1^{\circ} \mathrm{C} \\
\text { horizontal wind speed: } \\
\pm 0.08 \mathrm{~m} \mathrm{~s}^{-1}, \text { and vertical } \\
\text { wind speed: } \pm 0.04 \mathrm{~m} \mathrm{~s}^{-1}\end{array}$ \\
\hline $\begin{array}{l}\text { National Wind Technology Center (M2) } \\
\text { tower with T-200 A temperature probe } \\
\text { and Met One WS-201 wind sensor } \\
\text { system-NWTC }\end{array}$ & 1 & $\begin{array}{l}2,5,10,20,50 \\
\quad \text { and } 80\end{array}$ & $\begin{array}{l}u \text { and } v \text { component of wind, } \\
\text { turbulence intensity, } \\
\text { temperature, and 2-m } \\
\text { relative humidity }\end{array}$ & $\begin{array}{l}\text { Temperature: } \pm 0.1^{\circ} \mathrm{C} \text {, wind } \\
\text { speed: } \pm 0.5 \mathrm{~m} \mathrm{~s}^{-1} \text {, and } \\
\text { wind direction: } \pm 3.6^{\circ}\end{array}$ \\
\hline $\begin{array}{l}\text { NREL National Wind Technology Center } \\
\text { (M4) tower with T-200 A } \\
\text { temperature probe, Met One SS-201 cup } \\
\text { anemometers, Met One SD-201 wind } \\
\text { vanes, ATI "K" Type 3D sonic ane- } \\
\text { mometers, and AIR AB-2AX pressure } \\
\text { probe-NWTC }\end{array}$ & 1 & $\begin{array}{c}3,10,15,26,30,50 \\
76,80,88,100 \\
131, \text { and } 134\end{array}$ & $\begin{array}{l}u, v, \text { and } w \text { component of } \\
\text { wind, turbulence intensity, } \\
\text { turbulent kinetic energy, } \\
\text { temperature, and relative } \\
\text { humidity }\end{array}$ & $\begin{array}{l}\text { Temperature: } \pm 0.1^{\circ} \mathrm{C} \\
\text { cup-wind speed: } \\
\pm 0.5 \mathrm{~m} \mathrm{~s}^{-1} \text {, sonic-wind } \\
\text { speed: } \pm 0.01 \mathrm{~m} \mathrm{~s}^{-1} \text {, and } \\
\text { wind direction: } \pm 3.6^{\circ}\end{array}$ \\
\hline $\begin{array}{l}\text { Leosphere/NRG WindCube, version } 1 \\
\text { (v1), profiling lidars (WC68)—NWTC }\end{array}$ & 1 & $\begin{array}{c}40,60,80,100,120 \\
140,160,180,200 \\
\text { and } 220\end{array}$ & $\begin{array}{l}u, v \text {, and } w \text { component of } \\
\text { wind, turbulence intensity, } \\
\text { and turbulent kinetic } \\
\text { energy }\end{array}$ & Wind speed: $\pm 0.05 \mathrm{~m} \mathrm{~s}^{-1}$ \\
\hline $\begin{array}{l}\text { Leosphere/NRG WindCube, version } 2 \\
\text { (v2), profiling lidars (WC16)_XPIA }\end{array}$ & 1 & $\begin{array}{l}40,50,60,80,100 \\
120,140,160,180 \\
\text { and } 200\end{array}$ & $\begin{array}{l}u, v, \text { and } w \text { component of } \\
\text { wind, turbulence intensity, } \\
\text { and turbulent kinetic } \\
\text { energy }\end{array}$ & Wind speed: $\pm 0.05 \mathrm{~m} \mathrm{~s}^{-1}$ \\
\hline $\begin{array}{l}\text { Microwave radiometer-Radiometrics } \\
\text { MWR-3000A-XPIA/NWTC }\end{array}$ & 2 & $\begin{array}{c}50-6000 \mathrm{~m} \text { by } 50-\mathrm{m} \\
\text { intervals }\end{array}$ & $\begin{array}{l}\text { Temperature; relative } \\
\text { humidity }\end{array}$ & Temperature: $\pm 1^{\circ} \mathrm{C}$ \\
\hline
\end{tabular}

$$
\mathrm{TKE}=0.5\left(u^{\prime} u^{\prime}+v^{\prime} v^{\prime}+w^{\prime} w^{\prime}\right) .
$$

The variance of the wind components $\left(u^{\prime}, v^{\prime}\right.$, and $\left.w^{\prime}\right)$ is calculated over 2-min intervals, and we then calculate the maximum and mean TKE over the duration of GF passage.

In addition to the BAO towers, two meteorological towers at the NWTC (M2 and M4) are used in this analysis. At the NWTC M2 tower, wind every $2 \mathrm{~s}$ is sampled using Met One WS-201 instruments from which 1-min winds, maximum and mean TI are derived (specifics listed in Table 1). Met One T-200A temperature sensors sample every $2 \mathrm{~s}$ at only 2,50 , and $80 \mathrm{~m}$ AGL with 1-min average output and accuracies of $\pm 0.1^{\circ} \mathrm{C}$. Relative humidity and dewpoint temperature are sampled at $2 \mathrm{~m}$ every $2 \mathrm{~s}$ and averaged to 1 -min output (Jager and Andreas 1996; Johnson and Kelley 2000).

Observations from the NWTC M4 tower (Clifton et al. 2013) include Met One SS-201 cup anemometers and Met One SD-201 wind vanes that measure horizontal wind at $3,10,26,88$, and $134 \mathrm{~m}$ AGL with accuracies of
$0.5 \mathrm{~m} \mathrm{~s}^{-1}$ and $3.6^{\circ}$. In addition, 3D ATI "K"-Type sonic anemometers are mounted at 15, 30, 50, 76, 100, and $131 \mathrm{~m}$ AGL with accuracies of $0.01 \mathrm{~m} \mathrm{~s}^{-1}$. Maximum and mean TI are calculated from the cup anemometer observations, while maximum and mean TKE are derived from the 3D sonic anemometers. Temperature is measured at 3,26, and $88 \mathrm{~m}$ AGL using a Met One T-200A probe and at 15, 30, 50, 76, 100, and $131 \mathrm{~m}$ AGL using the ATI K-Type sonic anemometers with accuracies of $\pm 0.1^{\circ} \mathrm{C}$ for both instruments. Last, dewpoint temperature using a Therm-x 9400ASTD sensor and relative humidity are available at 3, 26, and $88 \mathrm{~m}$ AGL. All M-4 tower instruments sample at $20 \mathrm{~Hz}$ averaged to 1 -min output (Clifton et al. 2013; Clifton 2014). To avoid tower-wake impacts (Clifton 2014), we only consider winds between $25^{\circ}$ and $100^{\circ}$ and $175^{\circ}$ and $300^{\circ}$; we removed one event at the NWTC.

\section{c. Description of remote sensing research instruments}

In addition to tower observations, both sites use a Radiometrics MWR-3000A microwave radiometer and 
Leosphere/NRG WindCube lidars. A summary description of the microwave radiometer and WindCube lidars and their operations, including temporal and spatial resolution, as well as accuracy at each site, are shown in Table 1 and in Friedrich et al. (2012), Bianco et al. (2017), and Lundquist et al. (2017). The Radiometrics MWR3000A microwave radiometer provides vertical profiles of temperature and relative humidity (Solheim et al. 1998a, 1998b; Rosenkranz 1998). Vertical profiles of temperature and relative humidity are derived at 2-min intervals using a radiative transfer model and a 5-yr radiosonde climatology for Denver. Accuracy of the temperature retrieval was found to be within $\pm 1^{\circ} \mathrm{C}$ below $300 \mathrm{~m}$ AGL based on tower, radiosonde, and radiometer temperature intercomparisons at the NWTC and BAO (Friedrich et al. 2012; Lundquist et al. 2017; Bianco et al. 2017). Here, we use radiometer-retrieved temperature and humidity at $50,100,150$, and $300 \mathrm{~m}$ AGL to quantify changes in thermodynamics near the surface, and temperature up to $6 \mathrm{~km}$ to quantify the depth of cold air behind the leading edge of each GF.

Both sites also utilized measurements from Leosphere/NRG WindCube lidars. For events at the NWTC, data from a WindCube, version 1 (v1), profiling lidar (WC68) are used. The WindCube v1 lidar operates at the $1.5-\mu \mathrm{m}$ wavelength and samples line-of-sight (LOS) velocities across four cardinal directions each angled at $28^{\circ}$ from zenith. Each angled beam simultaneously samples 10 range gates (see Table 1 for measurement range heights) (Courtney et al. 2008; Lundquist et al. 2017). The v1 lidar derives horizontal and vertical velocities every $1 \mathrm{~Hz}$ using a Doppler beam swinging (DBS) approach [see Eqs. (1)-(3) in Lundquist et al. 2015] that are averaged to 1-min intervals. In the DBS approach, the backscattered radiation will create a shift in the frequency based on how rapidly particles are moving away or toward the lidar along each LOS. Vertical profiles of the LOS velocity can then be calculated by shifting the beam between the four radial wind directions, and by taking the difference between the arrival time of the backscatter and the initiation of the pulse at each measurement height (Lundquist et al. 2015). Using DBS-based wind field and its variance, the maximum and mean lidar TI and TKE (Rhodes and Lundquist 2013) are derived using Eqs. (1) and (2) at all available lidar heights. The WindCube v2 lidar, deployed during XPIA, is similar to the v1 version but operates with an additional fifth beam pointed at the zenith, which directly measures the vertical wind component. The v2 lidar sampling heights, different than the $\mathrm{v} 1$ lidar, and ranges are listed in Table 1 (Bodini et al. 2018). The accuracy of lidar-derived wind velocities is a function of an assumed horizontal homogeneity across the scanning cone at each height. In coastal flat areas, the WindCube accuracy is $\pm 0.05 \mathrm{~m} \mathrm{~s}^{-1}$ with a standard deviation of $0.15 \mathrm{~m} \mathrm{~s}^{-1}$ in sheared conditions (Sathe et al. 2011).

\section{Methods}

\section{Gust front detection and magnitude and rate change calculation}

Weather radars identify the leading edge of GFs as a line of enhanced radar reflectivity (also known as the radar fine line; Rauber and Nesbitt 2018). As the spreading cold air associated with a GF travels away from the parent thunderstorm, the air ahead of an advancing GF is lifted, insects and dust are lofted, and a shelf cloud can form, which become detectable by radar (Fig. 2; Wilson and Schreiber 1986; Rauber and Nesbitt 2018). To detect radar fine lines in this study, we use Level II radar reflectivity at the lowest elevation angle of $0.5^{\circ}$ observed from the Next Generation Weather Radar (NEXRAD) located at Denver (KFTG; Fig. 1). Level III radar products and Level II data are used to characterize the parent thunderstorms. Because KFTG is about 48 and $59 \mathrm{~km}$ southeast of the BAO and NWTC, respectively, the height of the lowest radar beam is about $0.6 \mathrm{~km}$ AGL over the BAO site and about $0.7 \mathrm{~km}$ AGL over the NWTC site. To determine GF events, we first identify days during the campaigns when thunderstorms developed in the vicinity of the instrument sites. Next, we classify GF events by visually identifying lines of enhanced (5-25 dBZ) reflectivity (Wilson and Schreiber 1986; Koch and Ray 1997) traveling away from parent thunderstorms and passing over the instruments (Fig. 2). During the XPIA and NWTC instrument operations, we identified 12 GFs passing over the NWTC and 12 GFs passing over the BAO. Radar observations are used to (i) characterize the parent thunderstorm (thunderstorm type, size, strength, and duration), (ii) analyze radarbased GF characteristics (propagation speed and direction and distance from parent thunderstorm at time of passage), and (iii) determine the relative time the GF passed over the instruments.

Parent thunderstorms are classified as single-cell, multicell, or supercell thunderstorms following Smith et al. (2012). We also characterize each parent thunderstorm $10 \mathrm{~min}$ prior to the time we first detect the radar fine line to compare among each case but also to compare the results to other studies. These characteristics include the maximum height at which radar reflectivity $Z \geq 18 \mathrm{~dB} Z$ (radar echo tops), maximum rainfall rate between the lowest and highest scan angle, and the areal extent of $Z \geq 35 \mathrm{~dB} Z$ at the lowest scan angle of each parent thunderstorm. Estimates of rainfall 


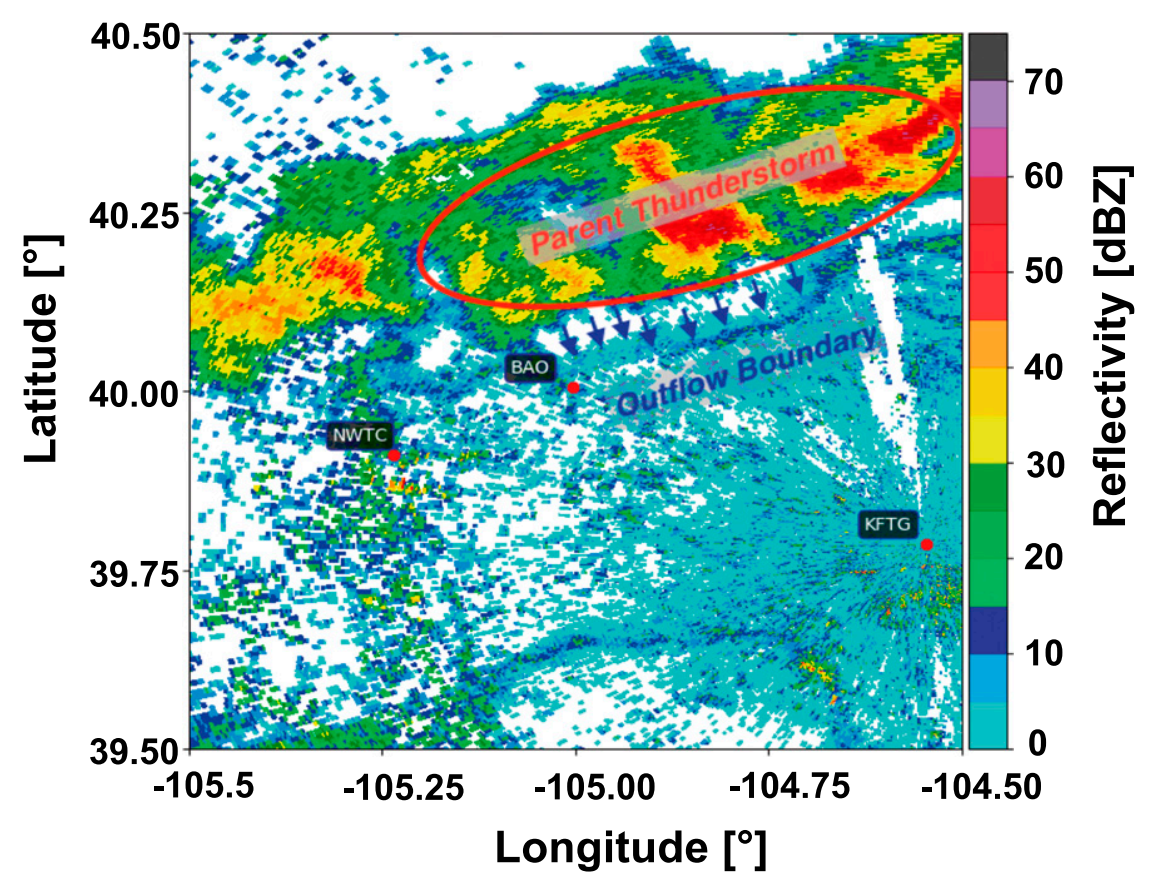

FIG. 2. Radar reflectivity at $0.5^{\circ}$ elevation angle showing a thunderstorm and GF passing over the BAO at 2120 UTC 3 May 2015 observed by the KTFG operational radar at Denver.

rate $R$ are derived from the relation $Z=300 R^{1.5}$. We also determine the parent thunderstorm duration from downdraft to dissipation stage, which is the time $10 \mathrm{~min}$ prior to the radar fine line detection and the time the parent thunderstorm dissipated $(Z<20 \mathrm{~dB} Z)$.

GF propagation speed is calculated using an observational technique tracking the radar fine line and then compared to the theoretical propagation speed for density currents. The observed propagation speed is calculated by tracking the radar-detected fine lines and calculating the displacement of the fine line signature over time as it approaches and eventually passes through the research sites. Considering that radar fine lines tend to morph into bowing or other irregular shapes, we account for this by determining an approximately $10-\mathrm{km}$ mean positional swath across the leading edge of the front as it moves over the instruments. The swath displacement is then tracked backward to calculate the mean propagation speed between the time the fine line was first detected and the time it passed over the instrument.

GFs are considered density currents with dense cold air propagating into an environment of less dense and warmer air. Therefore, the theoretical propagation speed for density currents explicitly incorporates cold-pool perturbations $\left(\Delta \theta ;{ }^{\circ} \mathrm{C}\right)$ and cold-air depth $h(\mathrm{~m})$ and can be considered to be a measure of GF intensity. It is calculated, following the method of Benjamin (1968), as

$$
c=\sqrt{\frac{\Delta \theta}{\theta} g h}
$$

where $c$ is the frontal propagation speed $\left(\mathrm{m} \mathrm{s}^{-1}\right), g$ is gravitational acceleration $\left(\mathrm{m} \mathrm{s}^{-2}\right)$, and $\theta$ is the ambient air temperature $\left({ }^{\circ} \mathrm{C}\right)$. We utilize $10 \mathrm{~m}$ measurements from the towers to calculate the cold-pool perturbation and ambient temperature prior to frontal passage. Here, we consider $h$ to be the depth of the trailing cold air behind the head of each GF. To obtain $h$, we use the 2 -min averaged vertical temperature profiles from the microwave radiometer between the surface and $6 \mathrm{~km}$ and determine the height at which the differences in temperature before and after the passage time is less than $1^{\circ} \mathrm{C}$, which corresponds to the accuracy of the temperature retrieval. The heights are determined with an accuracy of about $\pm 20 \mathrm{~m}$. Both radar-derived and theoretical propagation speed are analyzed and compared across all GF events.

For each GF that passed over the instrument site, we analyze the change in wind speed, wind direction, temperature, and relative humidity during the GF passage (referred to as magnitude change) and the time over which this magnitude change occurs (referred to as rate change). Magnitude and rate change are analyzed separately for each variable and measurement height (see example of GF-induced wind speed change in Fig. 3). To unambiguously identify the GF passage, an approximate 


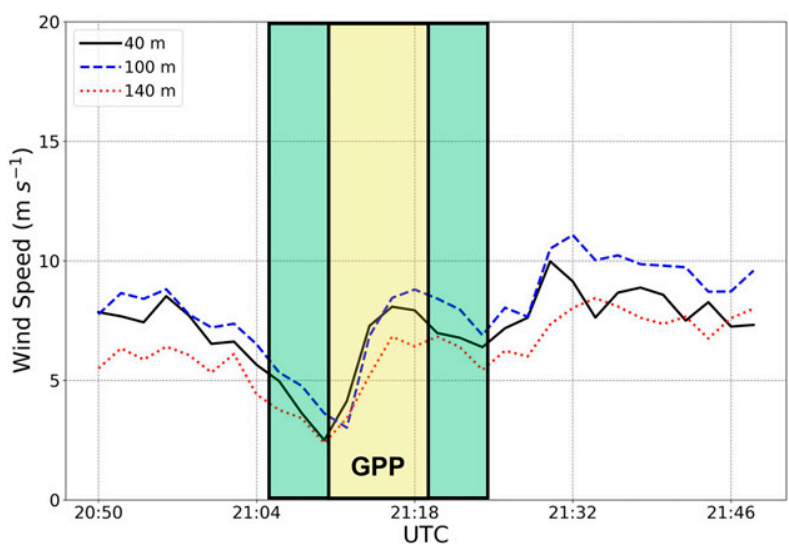

FIG. 3. Remotely sensed temporal evolution of wind speed at 40 (black solid line), 100 (blue dashed line), and 140 (red dotted line) $\mathrm{m}$ during a GF passage on 5 May 2015 over the BAO site. The white areas indicate the time $30 \mathrm{~min}$ prior to and $30 \mathrm{~min}$ after the radar-derived GF passage time. The yellow box represents the GPP. The green areas represent the 5-min intervals for which each variable is averaged to calculate the difference in the boundary variable prior to and after the GPP.

time over which GFs pass over the research sites is first derived by using KFTG radar data. In situ and remote sensing data are then analyzed $30 \mathrm{~min}$ before and $30 \mathrm{~min}$ after the radar-derived GF passage time (white shading shown in Fig. 3). Within this time frame, we determine the time period over which the largest gradient in the atmospheric variables occurs for each height level and each variable [yellow box in Fig. 3, referred to as GF passage period (GPP)]. Note that the GPP can differ depending on the instrument, measurement height, variable, and event. However, for the events discussed here the typical GPP for most of the variables occurs within the same time frame for each case, and the variance in GPP with height is negligible.

We then quantify the magnitude change for each variable by taking the difference between the 5 -min mean of the variable prior to and after the GPP (green boxes in Fig. 3). We perform a sensitivity analysis comparing 5-, 15-, and 30-min averages to determine which averaging time most accurately represents the change in GF variables (not shown). The results indicate that a 5-min period most accurately represents conditions prior and after the GPP for the cases analyzed in this study. The magnitude change is then divided by the GPP to obtain a gradient value normalized by the duration for each variable or rate change. We conduct a $t$ test to determine if the differences in magnitude and rate change between any of the variables observed at the NWTC and BAO are statistically significant when comparing the two study sites. As no statistically significant difference between the datasets is found $(p=0.05)$,
TABLE 2. List of dates for each of the 24 GF events and their corresponding campaign. Multiple GF events occurred on 4 and 16 Jun 2015 at the XPIA campaign site. The GF passage time is also included for each case.

\begin{tabular}{ccllc}
\hline \hline \multicolumn{2}{c}{ NWTC } & & \multicolumn{2}{c}{ XPIA } \\
\cline { 1 - 2 } \cline { 5 - 5 } Date & Time of passage & & \multicolumn{1}{c}{ Date } & Time of passage \\
\hline 5 Jun 2012 & 0115 UTC & & 3 May 2015 & 2120 UTC \\
2 Jul 2012 & 2314 UTC & & 31 May 2015 & 2022 UTC \\
7 Jul 2012 & 2218 UTC & & 1 Jun 2015 & 1941 UTC \\
16 Jul 2012 & 2141 UTC & & 3 Jun 2015 & 2353 UTC \\
25 Jul 2012 & 2128 UTC & & 4 Jun 2015 (1) & 2257 UTC \\
27 Jul 2012 & 1819 UTC & & 4 Jun 2015 (2) & 2324 UTC \\
1 Aug 2012 & 2112 UTC & & 7 Jun 2015 & 2251 UTC \\
18 Jun 2013 & 0244 UTC & & 13 Jun 2015 & 2251 UTC \\
23 Jun 2014 & 0042 UTC & & 16 Jun 2015 (1) & 2235 UTC \\
25 Jun 2014 & 2113 UTC & & 16 Jun 2015 (2) & 2317 UTC \\
26 Jun 2014 & 0141 UTC & & 24 Jun 2015 & 2345 UTC \\
27 Jun 2014 & 0722 UTC & & 25 Jun 2015 & 2151 UTC \\
\hline
\end{tabular}

we combine the measurements from the $\mathrm{BAO}$ and the NWTC sites and conduct a joint analysis of the 24 GF events.

Vertical profiles of changes in atmospheric variables are derived combining all available GF events. Note that while most measurement heights have data from only one instrument for each event, there are a few heights $(10,50,80,100,300 \mathrm{~m})$ where the instrument platforms overlap. At heights where an overlap occurs, we first merge the two datasets by averaging the measurements between the two instrument platforms. Differences in temperature are typically within $\pm 1^{\circ} \mathrm{C}$ when comparing the radiometer and in situ temperature probes and $\pm 1 \mathrm{~m} \mathrm{~s}^{-1}$ for horizontal wind between the lidars and wind anemometers. Vertical motion differences are negligible, within $\pm 0.5 \mathrm{~m} \mathrm{~s}^{-1}$ when comparing direct measurements from the 3D sonic anemometers and derived measurements using the v1 lidar DBS approach. Once we have data points representing each event for each measurement height, we calculate median and interquartile ranges.

\section{Results}

\section{a. Radar and gust front depth analysis}

During the instrument deployments, thunderstorms develop within close proximity to the study sites on 118 days with only $22(\sim 17 \%)$ days where observed radar fine lines propagate through the study sites (Table 2). As multiple GFs passed through the instrument sites on 2 separate days, a total of $24 \mathrm{GF}$ events are included in the following analysis. Ten $(\sim 42 \%)$ of the $24 \mathrm{GFs}$ initiate from single-cell thunderstorms, $13(\sim 54 \%)$ initiate from multicell cluster thunderstorm complexes, 

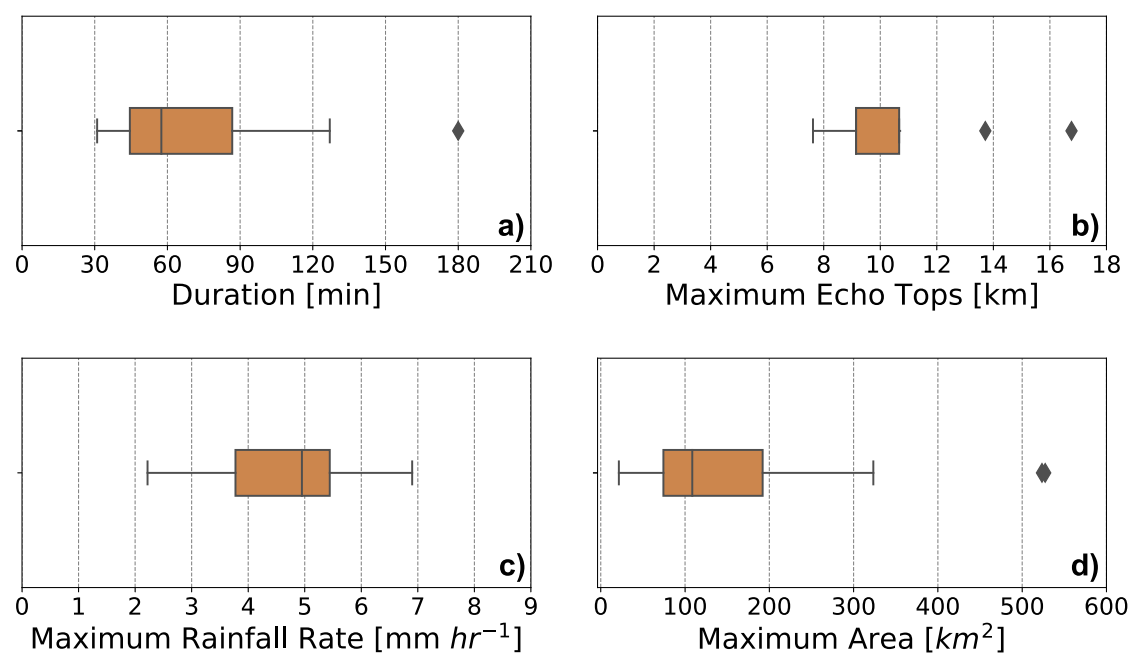

FIG. 4. Box-and-whisker plots of radar-derived parent thunderstorm characteristics. Variables analyzed include (a) duration from the time $10 \mathrm{~min}$ prior to GF detection and the time the parent thunderstorm dissipated $(Z<20 \mathrm{~dB} Z)(\mathrm{min})$, (b) parent thunderstorm maximum radar echo tops 10 min prior to GF detection $(\mathrm{km})$, (c) parent thunderstorm maximum rainfall rate from the lowest to highest can angle $10 \mathrm{~min}$ prior GF detection $\left(\mathrm{mm} \mathrm{h}^{-1}\right)$, and (d) parent thunderstorm areal extent of $Z \geq 35 \mathrm{~dB} Z$ at the lowest scan angle 10 min prior to GF detection $\left(\mathrm{km}^{2}\right)$. The filled box represents the interquartile range. The whiskers extend to data points that fall within 1.5 times the interquartile range of the lower and upper quantiles. Outliers that fall beyond this range are independently represented by diamond symbols.

and $1(4 \%)$ event stems from a supercell thunderstorm where rotation was evident in the radar Doppler velocity field. After the thunderstorms generate a GF, they continue to persist on average for another $58 \mathrm{~min}$, with a minimum persistence time of $31 \mathrm{~min}$ and a maximum of $180 \mathrm{~min}$ (Fig. 4a). Additionally, the median echo-top height $10 \mathrm{~min}$ prior to the first detection of each radar fine line was $9.1 \mathrm{~km}$ and the maximum related to the supercell thunderstorm was $16.8 \mathrm{~km}$ (Fig. 4b). Maximum rainfall rates $10 \mathrm{~min}$ prior to the first detection of each radar fine line ranges from 2.3 to $6.9 \mathrm{~mm} \mathrm{~h}^{-1}$ (Fig. 4c). Medium maximum areal extent within the $35-\mathrm{dB} Z$ isoline of each thunderstorm is $108 \mathrm{~km}^{2}$, with a maximum areal extent of $527 \mathrm{~km}^{2}$ (Fig. 4d).

Of the 24 GF events, $5(\sim 21 \%)$ GFs propagate from the southwest (rose diagrams in Fig. 1$), 2(\sim 8 \%)$ propagate from the southeast, $1(\sim 4 \%)$ propagates from the east, $7(\sim 29 \%)$ propagate from the northeast, $3(\sim 13 \%)$ propagate from the north, and $6(25 \%)$ propagate from the northwest. The median radar-derived GF propagation speed at time of passage is $7.6 \mathrm{~m} \mathrm{~s}^{-1}$ with a maximum and minimum propagation speed of 16.6 and $1.2 \mathrm{~m} \mathrm{~s}^{-1}$, respectively (Fig. 5a). Bryan and Rotunno (2008) show that observed GF propagation speed in the atmosphere can be as much as $25 \%$ slower relative to the theoretical speed, which applies better to laboratory flow or shallow density currents. Deeper atmospheric cold pools often show larger variations in density with height compared to laboratory flow. Faster theoretical propagation speeds are also observed in the cases discussed here with median values of $13.0 \mathrm{~m} \mathrm{~s}^{-1}$ and maximum and minimum propagation speeds of 24.6 and $4.7 \mathrm{~m} \mathrm{~s}^{-1}$, respectively. The correlation between radarderived propagation speed and the theoretical density current speed is 0.36 (statistically significant at $p<0.10$ ). While the depth of the observed cold pool is discussed later, we will now focus on the role of ambient wind ahead of the GF, which is not included in the theoretical propagation speed [Eq. (3)].

If we consider the influence of the prefrontal crossfront ambient wind component in the theoretical propagation speed calculation (following Simpson and Britter 1980; Jorgensen et al. 2003), we find that the theoretical propagation speed decreases in each case and the correlation between observed and theoretical propagation speed increases to 0.48 (statistically significant at $p<0.05$ ). Fitting the observed propagation speed to the prefrontal ambient wind through linear regression (Fig. 6), we find that faster GFs often do not have stronger tailwinds with $R^{2}=0.2$ (statistically significant at $p<0.05$ ). Since the ambient wind is not a strong determining factor for GF propagation speed in the cases discussed here, we will next investigate the role of topography. 

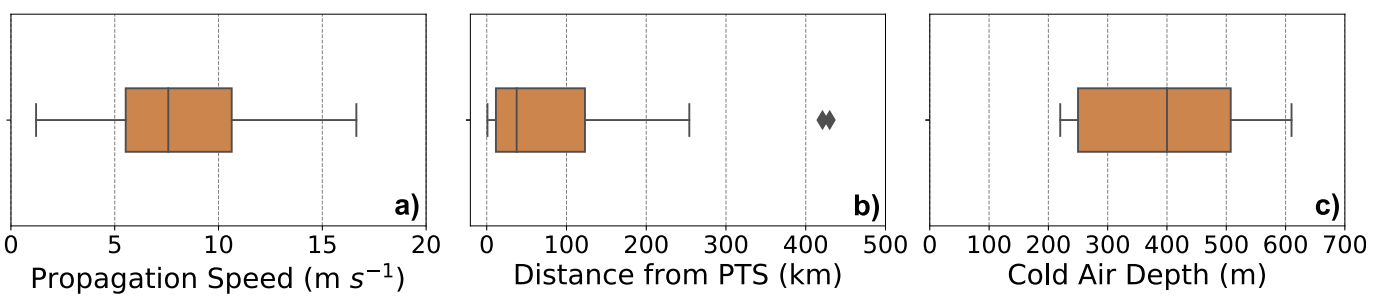

FIG. 5. Box-and-whisker plots of radar-derived thunderstorm and GF characteristics. Variables analyzed include (a) radar-derived propagation speed $\left(\mathrm{m} \mathrm{s}^{-1}\right)$, (b) distance from parent thunderstorm (PTS) (km), and (c) cold-air depth $(\mathrm{m})$. The filled box represents the interquartile range. The whiskers extend to data points that fall within 1.5 times the interquartile range of the lower and upper quantiles. Outliers that fall beyond this range are independently represented by diamond symbols.

Radar animations show that for GFs propagating from the north, the western periphery of these GFs drags along the Colorado Front Range mountains as they approach both instrument sites (figures not shown). This drag might be the reason that the southwardmoving GFs are slower (mean propagation speed of $6.6 \pm 3.3 \mathrm{~m} \mathrm{~s}^{-1}$ ), relative to the other propagation directions with a collective mean propagation speed of $10.1 \pm 3.8 \mathrm{~m} \mathrm{~s}^{-1}$. The differences in observed propagation speed among these groups are statistically significantly different at $p<0.05$; differences in theoretical propagation speed are statistically significantly different at $p<0.05$, with and without the inclusion of the prefrontal cross-front ambient wind component. The prefrontal cross-front ambient wind speed is on average $4.0 \mathrm{~m} \mathrm{~s}^{-1}$ for southwardmoving GFs, and $3.7 \mathrm{~m} \mathrm{~s}^{-1}$ for all other propagation directions. However, when we also consider the direction of the ambient wind component in relation to the propagation vector, the prefrontal wind decelerates the southwardmoving GFs on average by $-0.3 \mathrm{~m} \mathrm{~s}^{-1}$ and accelerates the non-southward-moving GFs on average by $+2.6 \mathrm{~m} \mathrm{~s}^{-1}$. Furthermore, at the BAO, all except GFs from the southwest propagate uphill (Fig. 7a), but the slope variability is the largest from the north and northwesterly directions (Table 3). At the NWTC, GFs approaching from the north, northeast, east, and southeast must travel uphill to reach the study site (Fig. 7b) with the highest variability in slope when they propagate from northeast and north (Table 3). Because the six slowest GF events approached the BAO and NWTC sites from the north and northwesterly directions, both higher variability in slope and elevation are hypothesized to have contributed to the deceleration of GFs for those size events. Especially considering that the prefrontal cross-front ambient wind component marginally contributes to the deceleration of southwardmoving GFs. Conversely, for non-southward-moving GFs, perhaps the acceleration due to the prefrontal cross-front ambient wind coupled with encountering less terrain slope variability partially explains the faster propagation speeds from these events.
As the spreading cold air of the GF begins to warm due to mixing and friction as it propagates farther away from the parent thunderstorm, the pressure gradient and surface winds weaken (Cotton et al. 2011). Distance from the parent thunderstorm at the time of passage in combination with the cold-pool depth and temperature difference between GF and ambient air can be used to characterize GFs (Craig Goff 1976; Cotton et al. 2011). In our study, the median distance from the parent thunderstorm at time of passage is $38 \mathrm{~km}$ across all 24 GF events (Fig. 5b). The correlation between distance from parent thunderstorm and maximum wind gusts observed at the $10-\mathrm{m}$ measurement height is negative at -0.32 (not statistically significant) (Fig. 8).

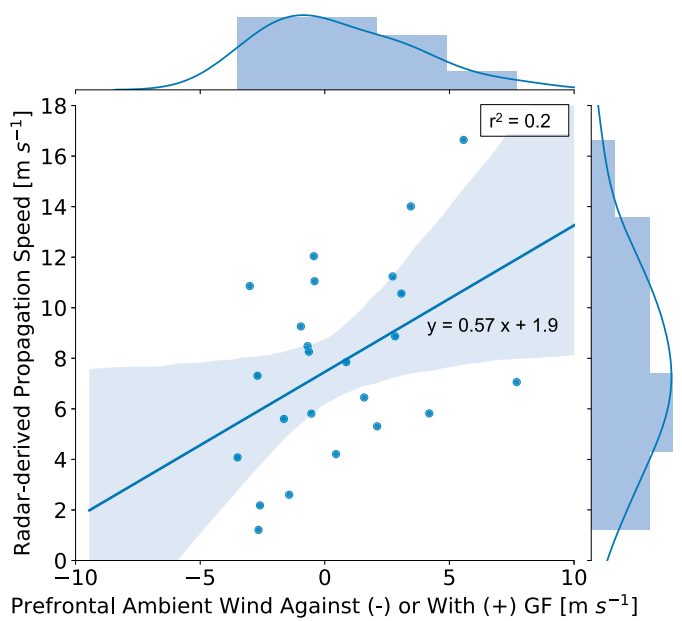

FIG. 6. Comparison of radar-derived propagation speed $\left(\mathrm{m} \mathrm{s}^{-1}\right)$ as a function of the prefrontal cross-front ambient wind component $\left(\mathrm{m} \mathrm{s}^{-1}\right)$. The prefrontal cross-front ambient wind components are derived by wind anemometers deployed on towers and measured at $10 \mathrm{~m}$ above the surface. The variance explained is listed in the upper-right corner. In addition, a linearly regressed fit is plotted as the solid blue line. The light-blue-shaded regions surrounding the regressed fit represent the $95 \%$ confidence intervals of the regression. In addition, the fitted distribution for each axis is displayed as histograms. 

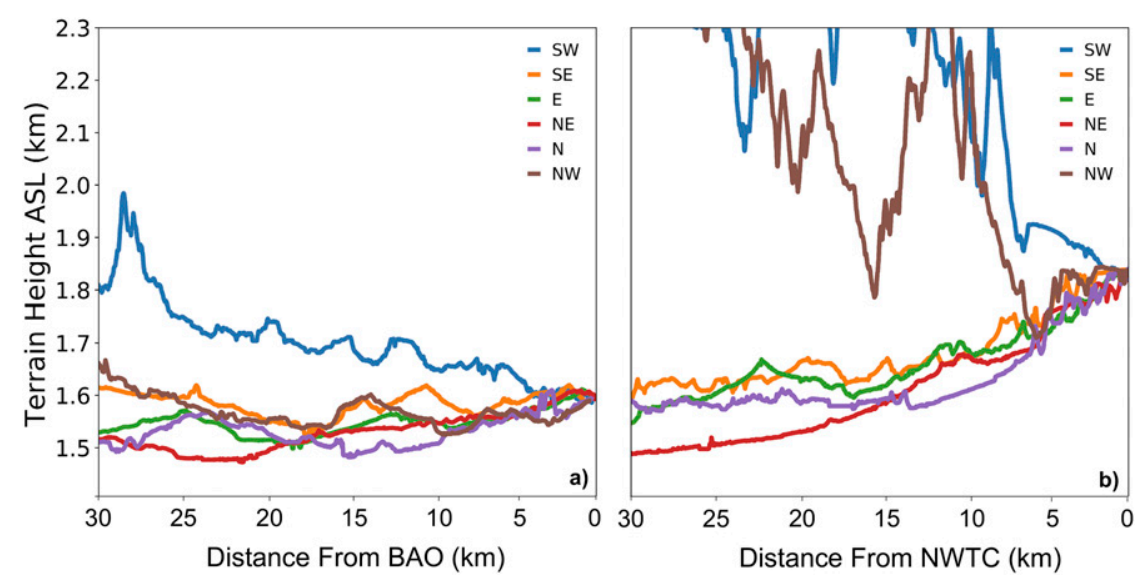

FIG. 7. Terrain height MSL $(\mathrm{km})$ along a $30-\mathrm{km}$ path extending from each GF propagation direction at (a) BAO and (b) NWTC. Terrain profiles are derived using data from the $1 / 3$ arc-s U.S. Geological Survey (USGS) National Elevation Dataset (NED).

Adding cold-pool depth and temperature difference shows that deeper cold air and larger temperature drops often but not always cause stronger wind gust events, which have a similar distance to their parent thunderstorm. The mean cold-air depth during GF passage is $360 \mathrm{~m}$ with a maximum cold-air depth of $610 \mathrm{~m}$ and a minimum of $220 \mathrm{~m}$ (Fig. 5c). The correlation between cold-air depth and the maximum wind gusts near the surface is 0.50 (statistically significant at $p<0.05$ ), supporting the theory that deeper cold air can induce stronger horizontal wind gusts (Benjamin 1968; Rotunno et al. 1988; Jorgensen et al. 2003). Similarly, the correlation between cold-air depth and the temperature drop near the surface is 0.48 (statistically significant at $p<0.05)$. Furthermore, the theoretical propagation speed (including the prefrontal ambient wind), which incorporates both cold-air depth and temperature deficit, also has a positive yet slightly lower correlation with temperature drop of 0.44 (statistically significant at $p<0.05$ ). Both of these correlations suggest that deeper cold air also causes stronger temperature drops near the surface in these 24 GFs. Last, the cold-air depth across the 24 GFs in this study is positively correlated with both the radar-derived propagation speed $(r=0.30)$ and the theoretical propagation speed (including the prefrontal ambient wind) $(r=0.62)$, supporting the theory that deeper cold air leads to faster propagating GFs (Benjamin 1968; Rotunno et al. 1988; Jorgensen et al. 2003).

\section{b. Magnitude and rate change during GF passage}

\section{1) Horizontal WIND SPEED}

The horizontal wind speed is observed by the lidars and tower anemometers to increase during GF passage in all analyzed events. Between the surface and $300 \mathrm{~m}$ AGL, the median magnitude change in wind speed with height ranges between 1 and $8 \mathrm{~m} \mathrm{~s}^{-1}$ (black solid line in Fig. 9a). Lower magnitude changes $<4 \mathrm{~m} \mathrm{~s}^{-1}$ are observed close to the surface ( $<25 \mathrm{~m}$ AGL). Above $25 \mathrm{~m}$, median magnitude changes are $4-5 \mathrm{~m} \mathrm{~s}^{-1}$. A peak in magnitude change of $8 \mathrm{~m} \mathrm{~s}^{-1}$ is observed at $120 \mathrm{~m}$. Four outlier events that extend beyond 1.5 times the interquartile range observe magnitude change in wind speeds upward of $6-12 \mathrm{~m} \mathrm{~s}^{-1}$. The duration of the wind speed change during GF passage ranges between 7 and

TABLE 3. Standard deviation of slope $\left(^{\circ}\right)$ and elevation $(\mathrm{km})$ along a $30-\mathrm{km}$ path extending from each GF propagation direction at both study sites. Elevation and slope calculations are based on data from the 1/3-arc-s USGS NED.

\begin{tabular}{|c|c|c|c|c|c|}
\hline \multicolumn{3}{|c|}{$\mathrm{BAO}$} & \multicolumn{3}{|c|}{ NWTC } \\
\hline Direction & Slope std dev $\left(^{\circ}\right)$ & Elev std dev (km) & Direction & Slope std dev $\left({ }^{\circ}\right)$ & Elev std dev $(\mathrm{km})$ \\
\hline SW & 2.9 & 0.07 & SW & 0.2 & 2.2 \\
\hline SE & 9.1 & 0.02 & SE & 7.6 & 0.07 \\
\hline $\mathrm{E}$ & 9.8 & 0.02 & $\mathrm{E}$ & 3.4 & 0.08 \\
\hline $\mathrm{NE}$ & 4.0 & 0.04 & $\mathrm{NE}$ & 11.9 & 0.09 \\
\hline $\mathrm{N}$ & 18.8 & 0.03 & $\mathrm{~N}$ & 24.3 & 0.08 \\
\hline NW & 19.1 & 0.03 & NW & 0.4 & 2.7 \\
\hline
\end{tabular}




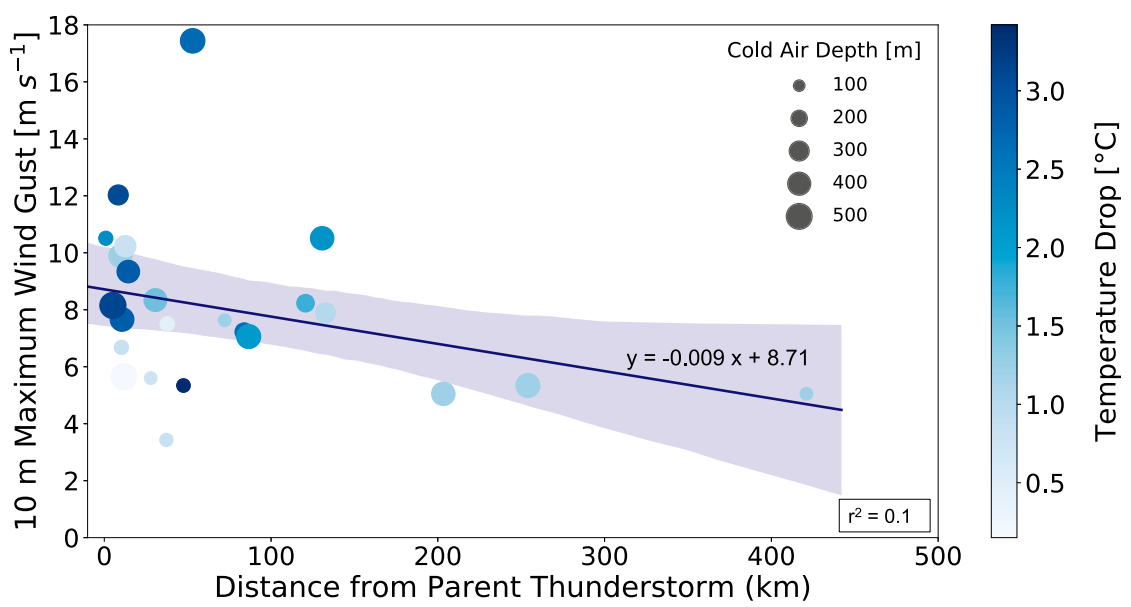

FIG. 8. Comparison of maximum wind gusts as the gust fronts passed over the instrument $\left(\mathrm{m} \mathrm{s}^{-1}\right)$ as a function of distance from parent thunderstorm at time of GF passage $(\mathrm{km})$. Maximum wind gusts are derived by wind anemometers deployed on towers and measured at $10 \mathrm{~m}$ above the surface. The variance explained is listed in the lower-right corner. In addition, a linearly regressed fit is plotted as the solid blue line. The gray-shaded regions surrounding the regressed fit represent the $95 \%$ confidence intervals of the regression. Larger-sized data points represent GFs with thicker trailing cold-air depths. Darker blue data points represent GFs associated with stronger temperature drops near the surface as they pass over the instruments.

13 min across all 24 events. The resulting median rate change in wind speed between the surface and $300 \mathrm{~m}$ AGL ranges between 0.2 and $0.7 \mathrm{~m} \mathrm{~s}^{-1} \mathrm{~min}^{-1}$ with nine outlier events where rate changes are $>1.5 \mathrm{~m} \mathrm{~s}^{-1} \mathrm{~min}^{-1}$ (Fig. 9b).

We also investigate if the propagation speed of GFs is correlated to the maximum near surface wind gusts (Craig Goff 1976; Mahoney 1988) as these gusts can influence fire spread. When correlating the radar-derived propagation speed to the maximum wind gusts measured at $10 \mathrm{~m}$ in this study, the relationship is positive and moderately strong with a correlation of 0.68 (statistically significant at $p<0.05$ ) and an $R^{2}$ value of 0.46 (Fig. 10a). The correlation is slightly lower at 0.61 when correlating the theoretical speed (including the prefrontal ambient wind) to the maximum observed wind gusts, yet still explains $37 \%$ of the variance in maximum wind gusts near the surface (Fig. 10b). Using tower observations from 20 gust fronts in Oklahoma, Craig Goff (1976) developed an empirical relationship between observed maximum wind gust and GF propagation speed of 1.49. In this study, we find the ratio of maximum wind gusts to radar-derived propagation speed to be 1.18. Mahoney (1988), who studied 30 GFs in the Colorado Front Range, also found a slightly higher ratio of 1.50. Larger ratios observed by Mahoney (1988) and Craig Goff (1976) results primarily from higher mean maximum wind gusts $\left[12.8 \mathrm{~m} \mathrm{~s}^{-1}\right.$ in both Craig Goff (1976) and $14.5 \mathrm{~m} \mathrm{~s}^{-1}$ in Mahoney (1988)].

\section{2) WIND DIRECTION}

Wind direction change associated with GFs is critical, as shown by several documented fire events in which the sudden change in wind direction from a passing GF led
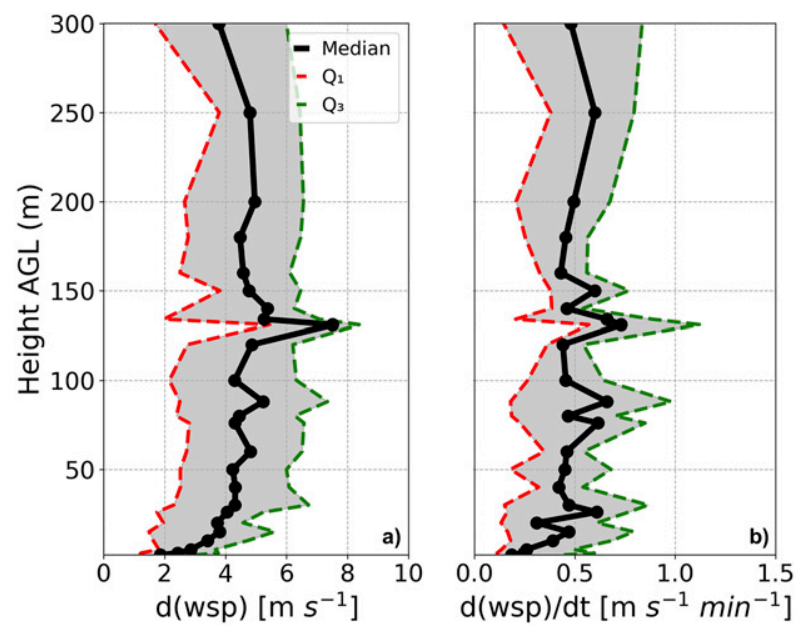

FIG. 9. Vertical profiles showing the (a) magnitude change $\left(\mathrm{m} \mathrm{s}^{-1}\right)$ and (b) rate change $\left(\mathrm{m} \mathrm{s}^{-1} \mathrm{~min}^{-1}\right)$ of wind speed (wsp) for the 24 events observed by the WindCube lidars and anemometers deployed on towers. The filled gray area represents the interquartile range, with the 25th (Q1) percentile denoted by the dashed red line and the 75th $(\mathrm{Q} 3)$ percentile denoted by the green dashed line. The filled circles indicate measurement points. The duration of wind speed change ranged from 7 to 13 min across all 24 events. 

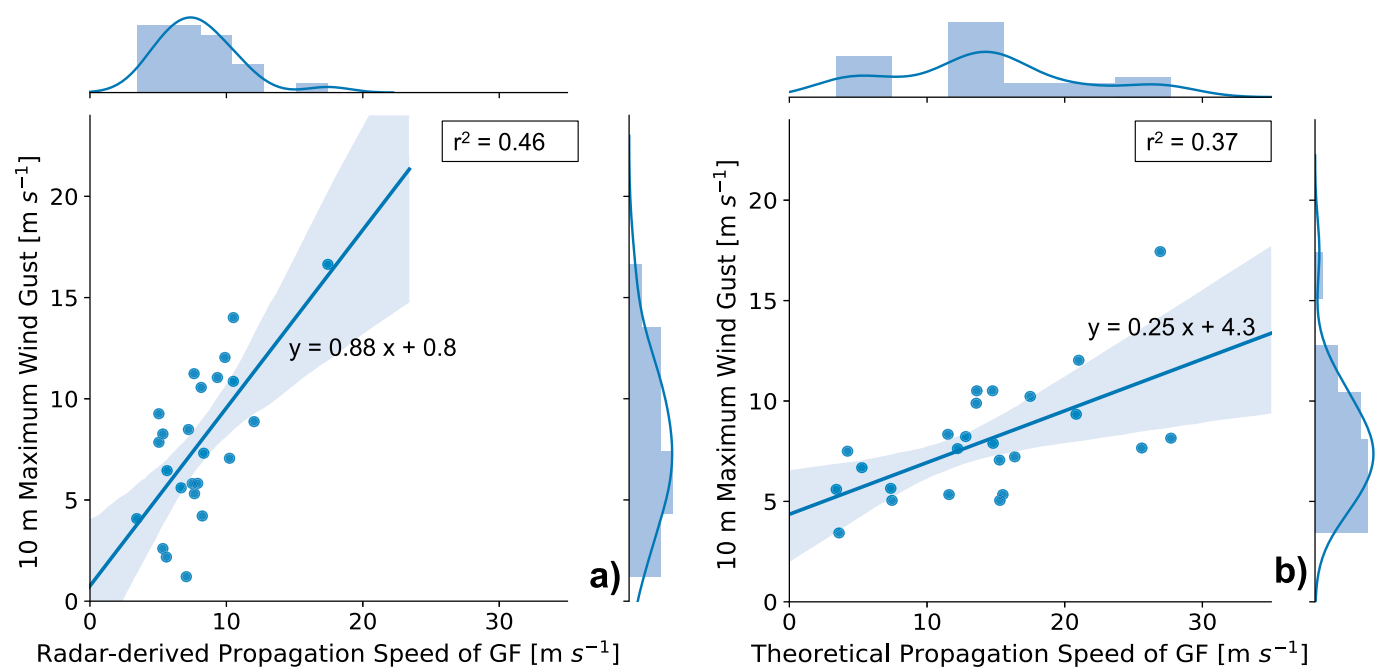

FIG. 10. (a) Comparison of maximum wind gusts as the GFs passed over the instrument $\left(\mathrm{m} \mathrm{s}^{-1}\right)$ as a function of propagation speed derived from the radar $\left(\mathrm{m} \mathrm{s}^{-1}\right)$ and (b) from the theoretical density current equation for 24 events. The variance explained is listed in the upper-right corners. In addition, linearly regressed fits are plotted as the solid blue lines. The light-blue-shaded regions surrounding the regressed fits represent the $95 \%$ confidence intervals of the regressions. In addition, the fitted distributions for each axis is displayed as histograms.

to loss of lives and property. Regardless of whether winds back or veer, here the median absolute magnitude change in wind direction ranges between $10^{\circ}$ and $60^{\circ}$ at all measurement heights observed by the lidars and anemometers (Fig. 11a). Similar to horizontal wind speed, the duration for wind direction change ranges between 7 and 16 min across all GF events. The resulting median rate change in wind direction is also nearly uniform in height ranging between $1^{\circ}$ and $6^{\circ} \min ^{-1}$ (Fig. 11b), suggesting that the rate at which the winds shift directions is mostly uniform through the lowest $300 \mathrm{~m}$ AGL. Outlier events are observed at all measurement heights and range from $14^{\circ}$ to $36^{\circ} \mathrm{min}^{-1}$.

\section{3) VERTICAL MOTION}

Vertical motion along the leading edge of all analyzed GFs behave as expected with maximum updrafts observed immediately prior to GF passage, followed by a spike in downward motion behind the leading edge of the boundary. Here, the median maximum updraft velocity observed using both the lidars and 3D sonic anemometers ranges between 0.4 and $2.0 \mathrm{~m} \mathrm{~s}^{-1}$ between 15 and $300 \mathrm{~m}$ AGL (Fig. 12a), with the median maximum downdraft velocity ranging between -0.3 and $-1.2 \mathrm{~m} \mathrm{~s}^{-1}$ (Fig. 12b). Six events experience maximum vertical motion $>2 \mathrm{~m} \mathrm{~s}^{-1}$ with a maximum updraft of $3.6 \mathrm{~m} \mathrm{~s}^{-1}$ at $300 \mathrm{~m}$ during one event measured.

\section{4) Turbulence}

Turbulence observed by the lidars and anemometers also behaves as expected by increasing during
GF passage for each the analyzed events. Median mean TI varies between 0.06 and 0.2 between the surface and $300 \mathrm{~m}$ AGL (Fig. 13a). Nine events experience maximum TI $>0.6$ during GF passage (Fig. 13b), while TI $>0.3$ occur during $14 \mathrm{GF}$ events. Median mean TKE (gustiness of the 3D wind) ranges from 0.2 to $1.7 \mathrm{~m}^{2} \mathrm{~s}^{-2}$ between 15 and $300 \mathrm{~m}$ (Fig. 14a). Maximum TKE is $>4 \mathrm{~m}^{2} \mathrm{~s}^{-2}$ during 14 of the $24 \mathrm{GF}$ events with a maximum of $6.2 \mathrm{~m}^{2} \mathrm{~s}^{-2}$ during one event (Fig. 14b).
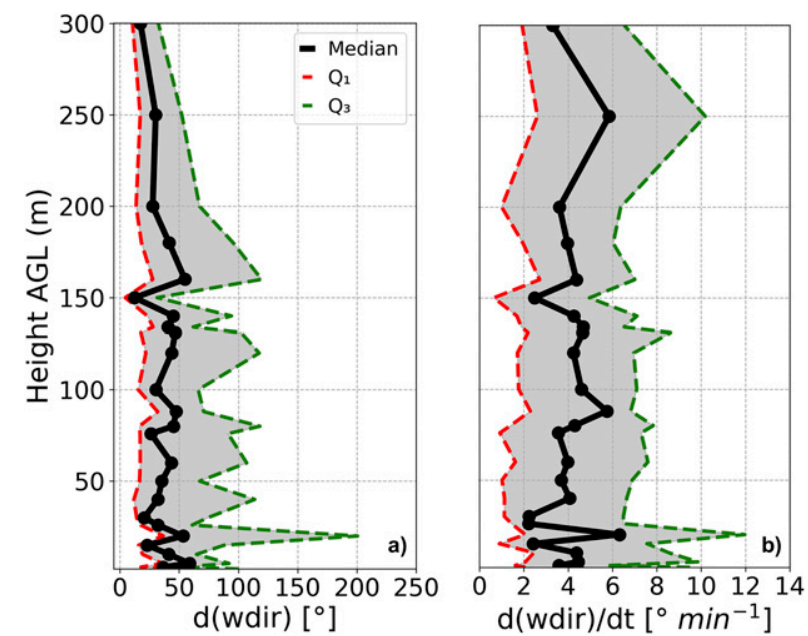

FIG. 11. As in Fig. 9, but showing the (a) magnitude change $\left({ }^{\circ}\right)$ and (b) rate change $\left({ }^{\circ} \mathrm{min}^{-1}\right)$ in wind direction (wdir) observed by the lidars and tower anemometers. The duration of wind direction change ranged from 7 to $16 \mathrm{~min}$ across all 24 events. 

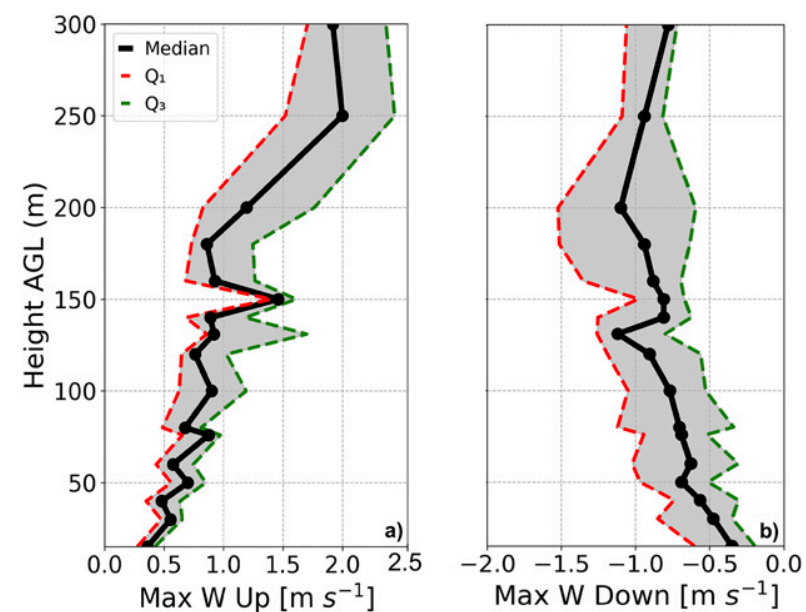

FIG. 12. As in Fig. 9, but showing the (a) maximum upward velocity $\left(\mathrm{m} \mathrm{s}^{-1}\right)$ and (b) maximum downward velocity $\left(\mathrm{m} \mathrm{s}^{-1}\right)$ observed by the lidars and tower anemometers.

\section{5) Temperature}

Atmospheric temperature measured by the radiometer and tower probes decreases during passage in all $24 \mathrm{GF}$ events dropping on average by $0.2^{\circ}-3^{\circ} \mathrm{C}$ between 2 and $300 \mathrm{~m}$ AGL (Fig. 15a) with five outlier events with temperature drops of $>6^{\circ} \mathrm{C}$ extending beyond 1.5 times the interquartile range. The duration of temperature change ranges between 5 and $10 \mathrm{~min}$ across all $24 \mathrm{GFs}$. The resulting median rate of temperature change does not vary much with height, ranging between -0.04 and $-0.3^{\circ} \mathrm{C} \min ^{-1}$ from 2 to $300 \mathrm{~m}$ AGL (Fig. 15b). During nine events rate changes of $>0.5^{\circ} \mathrm{C} \mathrm{min}{ }^{-1}$ are observed.

\section{6) RELATIVE HUMIDITY}

Coincident with the decrease in temperature, relative humidity increases during GF passage during all 24 events. Here, median relative humidity measured by the radiometer and tower probes increases by $1 \%-8 \%$ between 2 and $300 \mathrm{~m}$ AGL as the GFs pass over the instruments (Fig. 16a). However, two outlier events at $2 \mathrm{~m}$ experience a stronger magnitude increase in relative humidity greater than $30 \%$. The median duration for relative humidity change is short at 10 min across all 24 GFs. The resulting median rate of change in relative humidity ranges between $0.1 \%$ and $0.8 \% \mathrm{~min}^{-1}$ with little variation with height (Fig. 16b). Six outlier events are observed where the rate change is $>3 \% \mathrm{~min}^{-1}$.

\section{Discussion}

\section{a. Parent thunderstorm characteristics}

Comparing parent thunderstorm characteristics observed in this study to studies of organized thunderstorms like
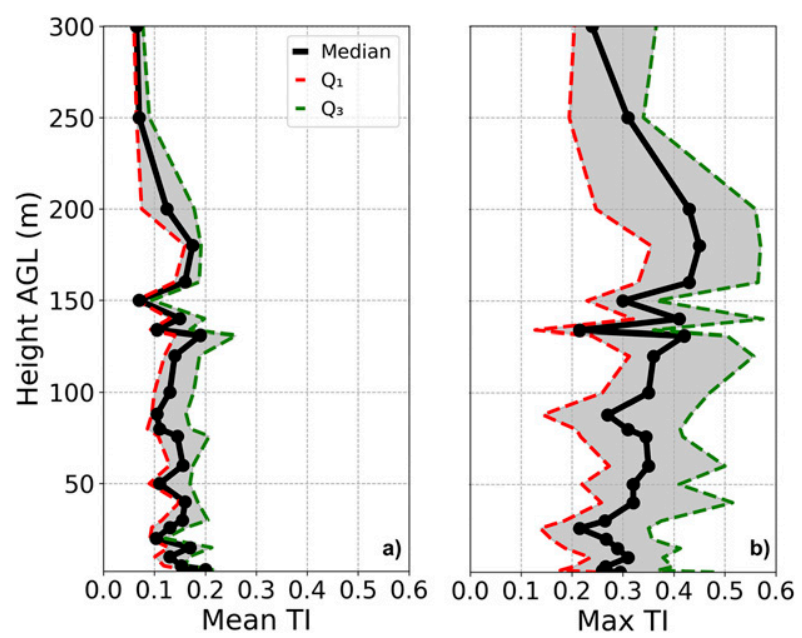

FIG. 13. As in Fig. 9, but showing the (a) mean and (b) maximum in TI observed by the lidars and tower anemometers.

supercell thunderstorms, squall lines, or MCSs in flatter regions can be challenging considering that there is little uniformity on how to quantify and characterize parent thunderstorms in GF studies. MCS thunderstorms, for example, are characterized by having a region of $Z \geq 40 \mathrm{~dB} Z$ that extends more than $100 \mathrm{~km}$ in at least one direction, and with durations between 3 and $24 \mathrm{~h}$ (e.g., Houze 1993; Parker and Johnson 2000; Schumacher and Johnson 2006). Other interpretations require reflectivity of at least $35 \mathrm{dBZ}$ along at least $50 \%$ of the $100-\mathrm{km}$ thunderstorm line to be considered an organized MCS (Provod et al. 2016). Supercell thunderstorm are usually not characterized by spatial extent but rather having a lifetime of $1-4 \mathrm{~h}$, a weak echo region, a mesocyclone, high lightning flash rate (Moller et al. 1994;
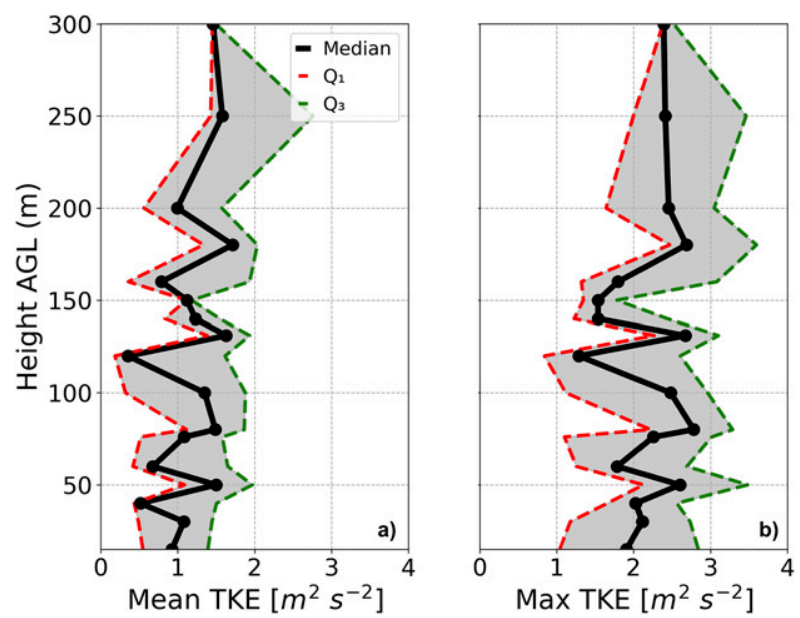

FIG. 14. As in Fig. 9, but showing the (a) mean $\left(\mathrm{m}^{2} \mathrm{~s}^{-2}\right)$ and (b) maximum $\left(\mathrm{m}^{2} \mathrm{~s}^{-2}\right)$ in TKE observed by the lidars and tower anemometers. 

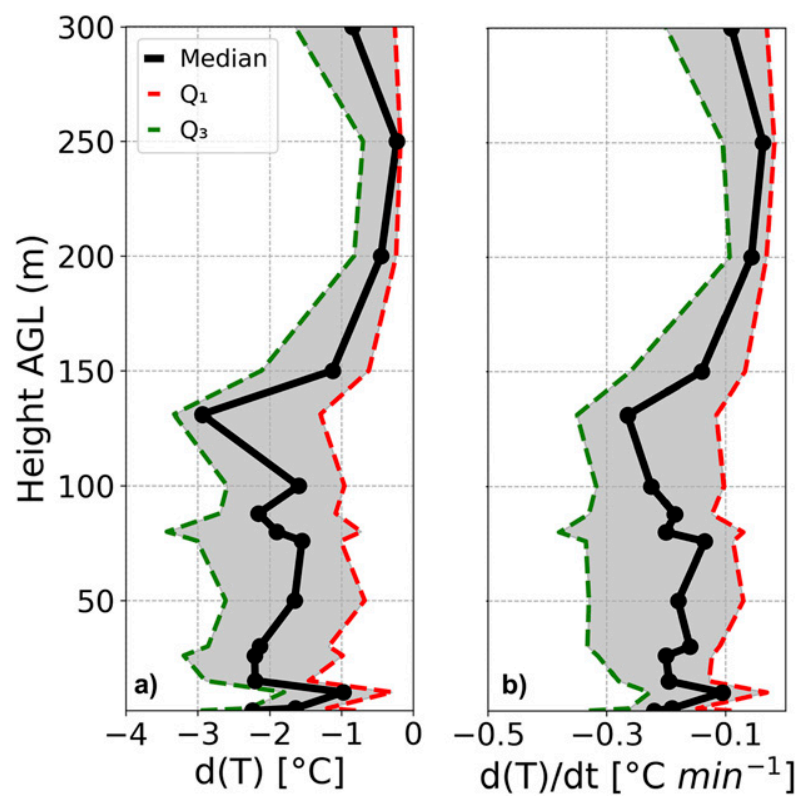

FIG. 15. As in Fig. 9, but showing the (a) magnitude change $\left({ }^{\circ} \mathrm{C}\right)$ and (b) rate change $\left({ }^{\circ} \mathrm{C} \mathrm{min}{ }^{-1}\right)$ in temperature $T$ observed by the radiometer and temperature probes on the towers. The duration of temperature change ranged from 5 to $10 \mathrm{~min}$ across all 24 events.

Bunkers et al. 2006). Given these inconsistencies and lack of uniformity, here we discuss the general characteristics of the primarily single and multicell thunderstorms in this study.

The median parent thunderstorm duration of $58 \mathrm{~min}$ (Fig. 4a) across the 24 GF events in this study is typical for single and multicell thunderstorms. In addition, the median maximum areal extent (within the region with $Z \geq 35 \mathrm{dBZ}$ ) of $108 \mathrm{~km}^{2}$ (Fig. $4 \mathrm{~d}$ ) is also indicative of spatially smaller thunderstorms. Rainfall rates and echo-top heights in the parent thunderstorms discussed here are also low. The maximum rainfall rate prior to GF detection was on average $\sim 5 \mathrm{~mm} \mathrm{~h}^{-1}$, with minimum rain rates as low as $2-3 \mathrm{~mm} \mathrm{~h}^{-1}$ and maximum rain rates as high as $6-7 \mathrm{~mm} \mathrm{~h}^{-1}$ (Fig. 4c), typical of lower-reflectivity thunderstorms. Furthermore, while organized MCS or squall-line thunderstorms might feed and maintain GFs for a long time (Wilson and Schreiber 1986; Weisman and Klemp 1986; Engerer et al. 2008), in our study parent thunderstorms disconnected from the GF by either remaining stationary or propagated in opposite directions. Maximum echo tops (median $=9.1 \mathrm{~km}$; Fig. 4b) across the 24 GFs in this study are also subdued; however, high convective available potential energy (CAPE) thunderstorms generally have higher echo tops than lower CAPE thunderstorms. Therefore, the low echo-top heights observed here may be driven by differing CAPE, rather than thunderstorm type and magnitude.
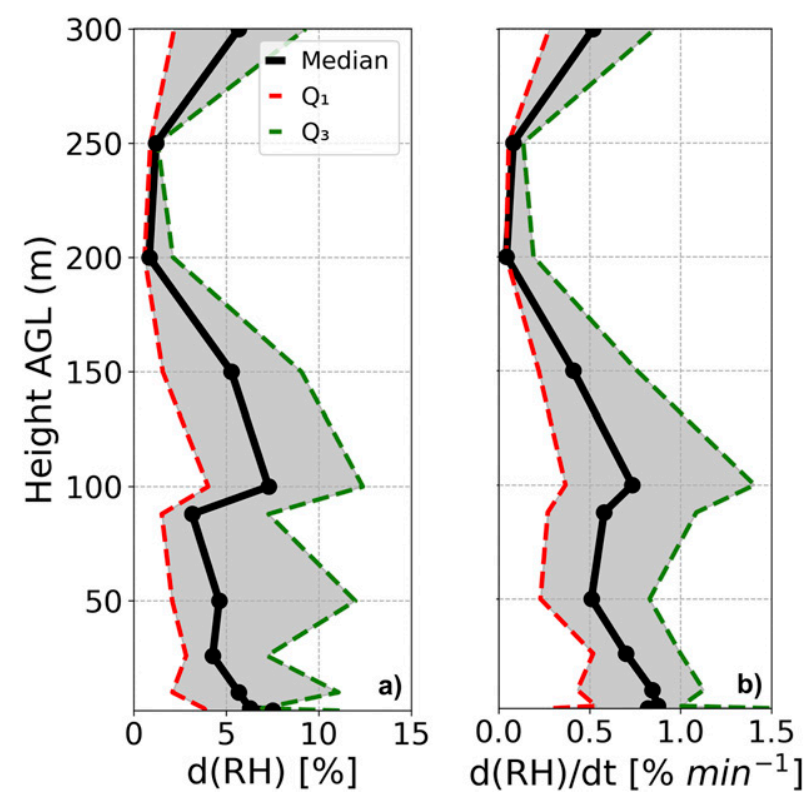

FIG. 16. As in Fig. 9, but showing the (a) magnitude change (\%) and $(b)$ rate change $\left(\% \mathrm{~min}^{-1}\right)$ in relative humidity $(\mathrm{RH})$ observed by the radiometer and moisture probes on the towers. The median duration of relative humidity change is $10 \mathrm{~min}$ across all 24 events.

Organized supercell or linear thunderstorms in the Colorado Front Range are rare, and, therefore, the low rainfall rates, small areal extents, and short durations from the primarily single and multicell parent thunderstorms in this study are representative of the thunderstorms that typically initiate across the mountains in the Colorado Front Range.

\section{b. Cold-air depth}

Density differences across the GF and the depth of cold air trailing thunderstorm GFs are related to their propagation speed, wind gusts, and associated changes in other atmospheric characteristics near the surface (Benjamin 1968; Craig Goff 1976; Mahoney 1988; Rotunno et al. 1988; Jorgensen et al. 2003). The mean cold-air depth of $360 \mathrm{~m}$ across the 24 GFs is much shallower when compared with studies of GFs from organized convection in flatter regions where cold pools are mainly $\sim 0.5-2 \mathrm{~km}$ deep but can reach depth of $>4 \mathrm{~km}$ in MCSs (Wakimoto 1982; Roux 1988; Bryan 2005; Bryan and Parker 2010; Cotton et al. 2011). Mahoney (1988) also measured an average depth of $1.2 \mathrm{~km}$ across 30 GFs observed in the Colorado Front Range, deeper than the cold air measured here.

However, establishing a relationship between coldpool depth and changes in atmospheric characteristics across different studies is often limited to the differences in how and where cold-pool depth is determined. Cold-air depth is sometimes derived using temperature profiles 
from in situ measurements (e.g., Wakimoto 1982; Roux 1988; Bryan and Parker 2010), while other methods determine cold-pool depth through the kinematic field using Doppler radar data (e.g., Mahoney 1988). Similarly, studies measure the cold-pool depth at different GF stages or distances from the parent thunderstorm, as well as determine the depth either through continuous tracking (Lagrangian approach; e.g., Mahoney 1988; Bryan and Parker 2010) or by taking a measurement at a single fixed location in time (Eulerian approach; e.g., Wakimoto 1982; Roux 1988). As we use an Eulerian approach limited to a fixed instrumentation site, we may not capture the deepest cold air associated with the peak intensity of each of the 24 GFs. Instead, we generally characterized weaker, older boundaries that were farther away from their parent thunderstorms (median distance $=38 \mathrm{~km}$ ) and therefore may have already mixed with the warmer environmental air before passing through the study sites. Similarly, Mahoney (1988) also notes that for the 30 GFs in the Colorado Front Range they analyzed, it was the older, weaker boundaries that generally had shallower cold-air depths.

\section{c. Horizontal wind speed}

Wind dynamics associated with passing GFs can rapidly change fire behavior, which can limit response effectiveness and, most important, threaten firefighter lives (Joint Fire Science Program 2017). During the 2013 Arizona Yarnell Fire GF accident, for example, the nearest surface meteorological station measured GF wind speed change in the $13-17 \mathrm{~m} \mathrm{~s}^{-1}$ range during the GF interaction with the fire (Karels and Dudley 2013). In addition, during the Florida Ransom Road Fire in 1981 , GF-induced wind speed change of $3-10 \mathrm{~m} \mathrm{~s}^{-1}$ and maximum wind gusts as high as $23 \mathrm{~m} \mathrm{~s}^{-1}$ were measured at a nearby meteorological tower during the period when two individuals were engulfed by the fire (Haines 1988). The magnitude wind speed changes of $1-8 \mathrm{~m} \mathrm{~s}^{-1}$ (with outliers of 6-12 $\mathrm{m} \mathrm{s}^{-1}$, and maximum wind gusts as high as $17.4 \mathrm{~m} \mathrm{~s}^{-1}$ ) observed along the Colorado Front Range are comparable to those observed during those fires.

Although the median magnitude change in horizontal winds appear to vary little with height, a low-level jetlike profile (or "GF nose-shape" profile) is observed to peak near $120 \mathrm{~m}$ AGL (Fig. 9a). Similar low-level jetlike structures and maximum horizontal winds near $120 \mathrm{~m}$ have been observed and modeled in other GF studies (Hjelmfelt 1988; Bowen 1996; Kwon and Kareem 2009; Kwon et al. 2012). Considering that typical tower heights for utility wind turbines range between 45 and $105 \mathrm{~m}$ (American Wind Energy Association 2008; Kwon et al. 2012), low- to midrise structures would potentially be exposed to the maximum median change in horizontal winds observed across the GFs in this study.

Mean rate change in wind speed of $0.2-0.7 \mathrm{~m} \mathrm{~s}^{-1} \mathrm{~min}^{-1}$ (with rate changes of $>1.5 \mathrm{~m} \mathrm{~s}^{-1} \mathrm{~min}^{-1}$ for individual cases) observed along the Colorado Front Range are also lower than in other studies. Zhang et al. (2018) observe a wind speed rate change of $1.5-2 \mathrm{~m} \mathrm{~s}^{-1} \mathrm{~min}^{-1}$ over $10 \mathrm{~min}$ in $88(63 \%)$ of 141 GFs that are detected along the coastal plains of the northern Mediterranean Sea coast. They observe wind speed rate changes from 2 to $3.5 \mathrm{~m} \mathrm{~s}^{-1} \mathrm{~min}^{-1}$ during the remaining 53 (37\%) GF events.

The mean maximum horizontal wind gusts observed near the surface in this study is $7.9 \mathrm{~m} \mathrm{~s}^{-1}$, weaker than what is typically associated with GFs that initiate from organized convection in flatter terrain. For example, mean maximum wind gusts of $15 \mathrm{~m} \mathrm{~s}^{-1}$ are associated with $39 \mathrm{GFs}$ that initiated from organized MCSs in Oklahoma (Engerer et al. 2008). Since most of the GF events in this study originate from single and multicell thunderstorms, the difference in organization and downdraft strength (i.e., depth of cold air at time of passage) may explain the weaker mean maximum wind gusts observed in this study. However, Mahoney (1988) observed mean maximum wind gusts of $12-14 \mathrm{~m} \mathrm{~s}^{-1}$ along $30 \mathrm{GFs}$ in the Colorado Front Range with several events occurring near the BAO tower. Therefore, GF-induced maximum wind gusts in this region can most definitely exceed the gusts associated with the GFs in this study.

\section{d. Wind direction}

While many studies emphasize the important role of wind direction change on fire behavior and intensity (Castro and Anderson 1981; Haines 1988; Goens and Andrews 1998; Kern et al. 2004; Johnson et al. 2014; Sharples et al. 2017), only few quantify change in wind direction associated with GF passages. During the 2013 Arizona Yarnell Hill Fire GF accident, the wind direction shifted $90^{\circ}$ during the GF passage, which undermined the decision-making of the firefighters (Karels and Dudley 2013). While thermodynamic variables like temperature change are weaker along the Colorado Front Range, the magnitude of wind direction ranges is still significant between $10^{\circ}$ and $60^{\circ}$ in our study, strong enough to significantly redirect fire behavior (Castro and Anderson 1981; Goens and Andrews 1998; Kern et al. 2004; Karels and Dudley 2013; Johnson et al. 2014).

\section{e. Vertical motion}

Understanding the location and strength of both the updraft and downdraft velocities associated with the leading edge of GFs is important for the landing and takeoff of airplanes (Federal Aviation Administration 1988, 2008, 2013; O’Connor and Kearney 2019). Vertical motion along 
the leading edge of GFs from organized severe supercell and MCS thunderstorms often exceeds $6 \mathrm{~m} \mathrm{~s}^{-1}$ and, in extreme cases, can reach upward of $15 \mathrm{~m} \mathrm{~s}^{-1}$ (Charba 1974; Craig Goff 1976; Wakimoto 1982; Martner 1997; Bryan and Parker 2010). GFs discussed in this study mainly observed weaker vertical velocities with maximum vertical motion in the $2-3.6 \mathrm{~m} \mathrm{~s}^{-1}$ range.

The weaker vertical motion observed across the GFs in this study may be related to the shallow cold air (mean depth $=360 \mathrm{~m}$ ) measured on average about $38 \mathrm{~km}$ from the parent thunderstorm (see section $5 \mathrm{~b}$ ). Similar mean cold-air depths $(\sim 330 \mathrm{~m})$ and maximum updrafts (between 1.1 and $3.1 \mathrm{~m} \mathrm{~s}^{-1}$ ) are observed across 25 GFs from nonsevere, shallow convective systems in Wilbanks et al. (2015). In contrast, deeper cold air is present in many studies that feature stronger vertical motion along GFs from severe supercell and MCS thunderstorms (Charba 1974; Craig Goff 1976; Wakimoto 1982; Bryan and Parker 2010). Similarly, Mahoney (1988) who tracked the evolution of two colliding GFs (with cold-air depths of $\sim 1.5-2 \mathrm{~km}$ ) in the Colorado Front Range measured updrafts in the $3-9 \mathrm{~m} \mathrm{~s}^{-1}$ range. Therefore, observing stronger vertical motion along GFs in the Colorado Front Range is possible, especially if measurements are taken during the time when the deepest cold air is present. Here, however, the average cold-air depth at time of GF passage is shallow, perhaps explaining the relatively weak maximum updrafts.

\section{f. Turbulence}

The mean TI during GF passage observed in this study is similar to other studies that focus on GF loading effects on wind energy structures. For example, the mean TI observed during 144 GF events along the northern Mediterranean coastline ranged from 0.08 to 0.18 (Zhang et al. 2018), similar to the $0.06-0.20$ TI range observed in this study. High-turbulence environments (TI $>0.3$; TKE $>4 \mathrm{~m}^{2} \mathrm{~s}^{-2}$ ) have been linked to increased wear on wind turbines and an increase in operation and maintenance costs (Manwell et al. 2002; International Electrotechnical Commission 2005; Nguyen et al. 2011; Hadi et al. 2015; Lu et al. 2019). Considering that we observe short-duration spikes in maximum TI and TKE exceeding 0.3 and $4 \mathrm{~m}^{2} \mathrm{~s}^{-2}$, respectively, turbulence induced by the GF events along the Colorado Front Range could be strong enough to potentially negatively influence wind energy structures (Manwell et al. 2002; Hadi et al. 2015; Zhang et al. 2018). TI values between 0.1 and 0.2 and TKE values around $2 \mathrm{~m}^{2} \mathrm{~s}^{-2}$ are typically associated with the convective boundary layer (Stull 1988; Kumer et al. 2016). Short-duration spikes in TI and TKE during the passage of these GF events also often exceeded the turbulence associated with general buoyancy during unstable boundary layer conditions.

\section{g. Temperature}

Rapid shifts in temperature and moisture content associated with GF passage can also heavily influence fire behavior and spread near the surface (Hanley et al. 2013; Coen and Schroeder 2017; Coen et al. 2018). Cooler temperatures and increased moisture content from passing boundaries are associated with diminishing fire growth and intensity. For example, a decrease in fire intensity was observed during the 2004 East Fork Fire near Tallahassee, Florida, as a sea-breeze boundary interacted with the fire and filtered in cooler, moist ocean air (Hanley et al. 2013). A period of slowed fire growth during the 2014 California King Fire was also observed and partly attributed to an increase in atmospheric humidity (Coen et al. 2018).

Temperature decreases observed in our study $\left(0.2^{\circ}-3^{\circ} \mathrm{C}\right.$ with up to $6^{\circ} \mathrm{C}$ ) are again subdued relative to other studies. Temperature drops between $1.8^{\circ}$ and $13.1^{\circ} \mathrm{C}$ are observed at the surface from 38 GFs in Niger, Africa, that initiated from organized MCSs (Provod et al. 2016). Similarly, temperature drops beyond $10^{\circ} \mathrm{C}$ were observed for most of $39 \mathrm{GF}$ events that spawned from MCS events in Oklahoma, with a maximum drop of $17.1^{\circ} \mathrm{C}$ (Engerer et al. 2008). The shallow cold air (mean depth $=$ $360 \mathrm{~m}$ ) measured at time of passage across the 24 GFs in this study may partially explain the weaker temperature drops observed here compared to the MCS initiated GFs studied in Provod et al. (2016) and Engerer et al. (2008). However, direct comparisons with Provod et al. (2016) and Engerer et al. (2008) are difficult considering their methods used to calculate temperature deficits differed from this study in that they subtract the maximum temperature before the GF from the minimum after the GF, as opposed to using an averaging technique like the one applied here. Therefore, conclusions drawn from comparing temperature deficits from the mostly single and multicell thunderstorm GFs in this study to the MCS initiated GFs in those studies are somewhat limited.

\section{h. Relative humidity}

To put the magnitude changes of relative humidity of $1 \%-8 \%$ observed along the Colorado Front Range in perspective, an increase in relative humidity of $\sim 20 \%$ was observed over a period of slowed fire growth during the 2014 California King megafire (Coen et al. 2018). Likely, then, the increase in relative humidity observed during the 24 GF events in this study would not contribute to the diminished fire intensity. The increase in wind gusts associated with GF passage would most likely 
overshadow any diminishing effects from the drop in temperature and rise in moisture content.

\section{Conclusions}

Knowledge of GF propagation and atmospheric characteristics predominantly stems from studies of organized and severe supercell or MCS thunderstorms that develop in flatter terrain regions. This study focuses on GFs from mainly single and multicell thunderstorms in and near complex terrain in the Colorado Front Range, east of the Rocky Mountains. In this study, in situ and remote sensing observations are combined to quantify the magnitude and rate change of atmospheric variables that occur in $24 \mathrm{GF}$ events. Horizontal wind, turbulence (TI and TKE), vertical velocity, temperature, and humidity are analyzed in the lowest $300 \mathrm{~m}$ AGL using a remote sensing microwave radiometer, wind-profiling lidars, and in situ data from three meteorological towers. The main findings from this analysis are:

- The median radar-derived propagation speed was $7.6 \mathrm{~m} \mathrm{~s}^{-1}$ with a maximum of $16.6 \mathrm{~m} \mathrm{~s}^{-1}$, and the influence of the prefrontal cross-front ambient wind component on propagation speed was found to be negligible. However, GFs that encountered higher variability in terrain and slope (from the northerly directions) were on average slower $\left(6.6 \pm 3.3 \mathrm{~m} \mathrm{~s}^{-1}\right)$ when compared with the other propagation directions $\left(10.1 \pm 3.8 \mathrm{~m} \mathrm{~s}^{-1}\right)$. Variability in terrain slope and elevation influenced the propagation speed of GFs in this study.

- Magnitude changes in temperature $\left(0.2^{\circ}-3^{\circ} \mathrm{C}\right)$, maximum vertical velocities $\left(2-3.6 \mathrm{~m} \mathrm{~s}^{-1}\right)$, and maximum wind gusts (mean $=7.9 \mathrm{~m} \mathrm{~s}^{-1}$ ) observed here are generally weaker than in studies of GFs initiating from organized, severe thunderstorms in flatter terrain. The average cold-air depth is about $360 \mathrm{~m}$, shallower than in other studies, which may explain the weaker magnitude changes observed in this study.

- While most wind energy GF studies focus on quantifying turbulence using 2D TI, this is one of the first studies that also evaluates the 3D TKE associated with GFs. Short-duration spikes in TKE $\left(>4 \mathrm{~m}^{2} \mathrm{~s}^{2}\right)$ occur in $14(58 \%)$ of the $24 \mathrm{GF}$ events, exceeding TKE values often associated with unstable boundary layer conditions.

Comparing GF characteristics among different types of thunderstorms and in different terrain is often challenging considering that methods and instruments used in GF studies are not always uniform. In particular, calculating the change in GF atmospheric characteristics is highly dependent on the interpretation of when the boundary passed over the instruments. A more uniform understanding of how to quantify the GF passage time would help to better facilitate regional comparisons. A future observational study could, therefore, address the influence of terrain on propagating GFs by comparing the magnitude change in GF boundary variables in this study to the magnitude change in GF boundary variables from single- or multicell thunderstorms in flatter terrain using similar methods and instruments. A future study should also expand this analysis to surface stations scattered across the Intermountain West. Statistically examining many more GF events in the complex terrain of this region would ideally further our understanding of how the underlying terrain may influence propagating GFs. The additional statistics could also help to validate numerical weather prediction models, which in the past have shown promise in their ability to accurately model GFs and other high-impact wind events in mountainous terrain (Coen and Riggan 2011; Coen et al. 2013; Johnson et al. 2014; Coen and Schroeder 2017; Coen et al. 2018; Jiménez et al. 2018; Muñoz-Esparza et al. 2018).

Acknowledgments. This research is supported through Award L17AC00227 (JFSP Project 17-1-05-2 Evaluating thunderstorm outflow boundaries in WRF-Fire) from the Bureau of Land Management as part of the Joint Fire Science Program under the subject opportunity FA-FON0017-0002. This work was authored in part by the National Renewable Energy Laboratory, operated by Alliance for Sustainable Energy, LLC, for the U.S. Department of Energy (DOE) under Contract DEAC36-08GO28308. Funding was provided by the U.S. Department of Energy Office of Energy Efficiency and Renewable Energy Wind Energy Technologies Office. The views expressed in the article do not necessarily represent the views of the DOE or the U.S. government. The U.S. government retains and the publisher, by accepting the article for publication, acknowledges that the U.S. government retains a nonexclusive, paid-up, irrevocable, worldwide license to publish or reproduce the published form of this work, or allow others to do so, for U.S. government purposes. The authors acknowledge and thank the reviewers of this paper whose suggestions strengthened the fundamentals of this article.

\section{REFERENCES}

Aitken, M. L., R. M. Banta, Y. L. Pichugina, and J. K. Lundquist, 2014: Quantifying wind turbine wake characteristics from scanning remote sensor data. J. Atmos. Oceanic Technol., 31, 765-787, https://doi.org/10.1175/JTECH-D-13-00104.1.

American Wind Energy Association, 2008: Annual Wind Industry Report-Year Ending 2008. AWEA Doc., 68 pp., https:// www.nrel.gov/docs/fy09osti/46026.pdf. 
Ashley, W. S., A. M. Haberlie, and J. Strohm, 2019: A climatology of quasi-linear convective systems and their hazards in the United States. Wea. Forecasting, 34, 1605-1631, https://doi.org/ 10.1175/WAF-D-19-0014.1.

Banta, R. M., L. D. Olivier, and P. H. Gudiksen, 1993: Sampling requirements for drainage flows that transport atmospheric contaminants in complex terrain. Radiat. Protection Dosim., 50, 243-248, https://doi.org/10.1093/oxfordjournals.rpd.a082094.

Benjamin, T. B., 1968: Gravity currents and related phenomena. J. Fluid Mech., 31, 209-248, https://doi.org/10.1017/ S0022112068000133.

Bianco, L., K. Friedrich, J. Wilczak, D. Hazen, D. Wolfe, R. Delgado, S. Oncley, and J. K. Lundquist, 2017: Assessing the accuracy of microwave radiometers and radio acoustic sounding systems for wind energy applications. Atmos. Meas. Tech., 10, 1707-1721, https://doi.org/10.5194/amt-101707-2017.

Bidokhti, A. A., and T. Bani-Hashem, 2001: Structure of thunderstorm gust fronts with topographic effects. Adv. Atmos. Sci., 18, 1161-1174, https://doi.org/10.1007/s00376-001-0030-4.

Bodini, N., J. K. Lundquist, and R. K. Newsom, 2018: Estimation of turbulence dissipation rate and its variability from sonic anemometer and wind Doppler lidar during the XPIA field campaign. Atmos. Meas. Tech., 11, 4291-4308, https://doi.org/ 10.5194/amt-11-4291-2018.

Bowen, B. M., 1996: Example of reduced turbulence during thunderstorm outflow. J. Appl. Meteor., 35, 1028-1032, https://doi.org/ 10.1175/1520-0450(1996)035<1028:EORTDT>2.0.CO;2.

Bryan, G. H., 2005: Spurious convective organization in simulated squall lines owing to moist absolutely unstable layers. Mon. Wea. Rev., 133, 1978-1997, https://doi.org/10.1175/MWR2952.1. , and R. Rotunno, 2008: Gravity currents in a deep anelastic atmosphere. J. Atmos. Sci., 65, 536-556, https://doi.org/10.1175/ 2007JAS2443.1.

— near environment using high-frequency rawinsonde launches during VORTEX2. Mon. Wea. Rev., 138, 4076-4097, https:// doi.org/10.1175/2010MWR3359.1.

Bunkers, M. J., M. R. Hjelmfelt, and P. L. Smith, 2006: An observational examination of long-lived supercells. Part I: Characteristics, evolution, and demise. Wea. Forecasting, 21, 673-688, https:// doi.org/10.1175/WAF949.1.

Castro, S. J., and C. R. Anderson, 1981: A report to the committee on appropriations, U.S. House of Representatives, on wildfire on Merritt Island. Surveys and Investigation Staff Rep., 34 pp., https://www.wildfirelessons.net/HigherLogic/System/ DownloadDocumentFile.ashx?DocumentFileKey=de70dc821760-487f-b1d4-05a8d11293cc\&forceDialog $=0$.

Charba, J., 1974: Application of gravity current model to analysis of squall-line gust front. Mon. Wea. Rev., 102, 140-156, https://doi.org/10.1175/1520-0493(1974)102<0140:AOGCMT> 2.0.CO;2.

Chay, M. T., F. Albermani, and R. Wilson, 2006: Numerical and analytical simulation of downburst wind loads. Eng. Struct., 28, 240-254, https://doi.org/10.1016/j.engstruct.2005.07.007.

Clifton, A., 2014: 135-m meteorological masts at the National Wind Technology Center. NREL Rep., 52 pp., https://wind.nrel.gov/ MetData/Publications/NWTC_135m_MetMasts.pdf.

— , and J. K. Lundquist, 2012: Data clustering reveals climate impacts on local wind phenomena. J. Appl. Meteor. Climatol., 51, 1547-1557, https://doi.org/10.1175/JAMC-D-11-0227.1.

—, S. Schreck, G. Scott, N. Kelley, and J. K. Lundquist, 2013: Turbine inflow characterization at the National Wind Technology
Center. J. Sol. Energy Eng., 135, 031017, https://doi.org/10.1115/ 1.4024068

Coen, J. L., and P. J. Riggan, 2011: A landscape-scale wildland fire study using coupled weather-wildland fire model and airborne remote sensing. Proc. Third Fire Behavior and Fuel Conf., Spokane, WA, International Association of Wildland Fire, 495-505, http://www.iawfonline.org/wp-content/uploads/2018/ 02/2010_FBF_Conference_Proceedings.pdf.

_ From research to operational forecasting. Fire Manage. Today, 75, 39-45.

_- M. Cameron, J. Michalakes, E. G. Patton, P. J. Riggan, and K. M. Yedinak, 2013: WRF-Fire: Coupled weather-wildland fire modeling with the weather research and forecasting model. J. Appl. Meteor. Climatol., 52, 16-38, https://doi.org/ 10.1175/JAMC-D-12-023.1.

— E. N. Stavros, and J. A. Fites-Kaufman, 2018: Deconstructing the king megafire. Ecol. Appl., 28, 1565-1580, https://doi.org/ 10.1002/eap.1752.

Cotton, W. R., R. L. George, P. J. Wetzel, and R. L. McAnelly, 1983: A long-lived mesoscale convective complex. Part I: The mountain-generated component. Mon. Wea. Rev., 111, 1893-1918, https://doi.org/10.1175/1520-0493(1983)111<1893:ALLMCC> 2.0.CO;2.

_, G. Bryan, and S. C. Van den Heever, 2011: Storm and Cloud Dynamics. International Geophysics Series, Vol. 99, Academic Press, $820 \mathrm{pp}$.

Courtney, M., R. Wagner, and P. Lindelow, 2008: Testing and comparison of lidars for profile and turbulence measurements in wind energy. IOP Conf. Ser.: Earth Environ. Sci., 1, 012021, https://doi.org/10.1088/1755-1315/1/1/012021.

Craig Goff, R., 1976: Vertical structure of thunderstorm outflows. Mon. Wea. Rev., 104, 1429-1440, https://doi.org/10.1175/15200493(1976)104<1429:VSOTO>2.0.CO;2.

Droegemeier, K. K., and R. B. Wilhelmson, 1987: Numerical simulation of thunderstorm outflow dynamics. Part I: Outflow sensitivity experiments and turbulence dynamics. J. Atmos. Sci., 44, 1180-1210, https://doi.org/10.1175/1520-0469(1987) 044<1180:NSOTOD $>2.0 . C O ; 2$.

Engerer, N. A., D. J. Stensrud, and M. C. Coniglio, 2008: Surface characteristics of observed cold pools. Mon. Wea. Rev., 136 4839-4849, https://doi.org/10.1175/2008MWR2528.1.

Federal Aviation Administration, 1988: Pilot windshear guide. U.S. Department of Transportation Doc. AC 00-54, 64 pp., https://www.faa.gov/documentLibrary/media/Advisory_Circular/ AC00-54.pdf.

— 2008: Thunderstorms_-Don't flirt. . .skirt 'em. U.S. Department of Transportation Doc. FAA-P-8740-12, 6 pp, https:// www.faasafety.gov/files/gslac/library/documents/2011/Aug/56397/ FAA \%20P-8740-12\%20Thunderstorms[hi-res]\%20branded.pdf.

_ 2013: Thunderstorms. U.S. Department of Transportation Doc. AC 00-24C, 13 pp., https://www.faa.gov/documentlibrary/ media/advisory_circular/ac\%2000-24c.pdf.

Friedrich, K., D. E. Kingsmill, and C. R. Young, 2005: Misocyclone characteristics along Florida gust fronts during CaPE. Mon. Wea Rev., 133, 3345-3367, https://doi.org/10.1175/MWR3040.1.

_, J. K. Lundquist, M. Aitken, E. A. Kalina, and R. F. Marshall, 2012: Stability and turbulence in the atmospheric boundary layer: A comparison of remote sensing and tower observations. Geophys. Res. Lett., 39, L03801, https://doi.org/10.1029/ 2011 GL050413.

Fujita, T. T., 1981: Tornadoes and downbursts in the context of generalized planetary scales. J. Atmos. Sci., 38, 1511-1534, 
https://doi.org/10.1175/1520-0469(1981)038<1511:TADITC $>$ 2.0.CO;2.

Goens, D. W., and P. L. Andrews, 1998: Weather and fire behavior factors related to the 1990 Dude Fire near Payson, AZ. Second Conf. on Fire and Forest Meteorology, Phoenix, AZ, Amer. Meteor. Soc., 153-158.

Hadi, F. A., S. T. Nassir, and R. A. Abdulwahab, 2015: Turbulence intensity calculation for Al-Shehabi site in Iraq. Int. J. $A d v$. Res. Electr. Electron. Instrum. Eng., 4, 7619-7627.

Haines, D. A., 1988: Downbursts and wildland fires: A dangerous combination. Fire Manage. Today, 49, 8-10.

Hanley, D. E., P. Cunningham, and S. L. Goodrick, 2013: Interaction between a wildfire and the sea-breeze front Remote Sensing and Modeling Applications to Wildland Fires, Springer, 81-98, https://doi.org/10.1007/978-3-642-32530-4_7.

Hardy, K., and L. K. Comfort, 2015: Dynamic decision processes in complex, high-risk operations: The Yarnell Hill Fire, June 30, 2013. Saf. Sci., 71, 39-47, https://doi.org/ 10.1016/j.ssci.2014.04.019.

Hjelmfelt, M. R., 1988: Structure and life cycle of microburst outflows observed in Colorado. J. Appl. Meteor., 27, 900-927, https://doi.org/10.1175/1520-0450(1988)027<0900:SALCOM> 2.0.CO;2.

Houze, R. A., Jr., 1993: Cloud Dynamics. Academic Press, 570 pp.

International Electrotechnical Commission, 2005: Wind turbines-Part 1: Design requirements. IEC Rep. 61400-3: TC88-MT, 64 pp.

Jager, D., and A. Andreas, 1996: NREL National Wind Technology Center (NWTC): M2 Tower: Boulder, Colorado (Data). NREL, accessed 10 July 2019, https://doi.org/10.5439/1052222.

Jiménez, P., D. Muñoz-Esparza, and B. Kosović, 2018: A high resolution coupled fire-atmosphere forecasting system to minimize the impacts of wildland fires: Applications to the Chimney Tops II wildland event. Atmosphere, 9, 197, https:// doi.org/10.3390/atmos9050197.

Johnson, R. H., R. S. Schumacher, J. H. Ruppert, D. T. Lindsey, J. E. Ruthford, and L. Kriederman, 2014: The role of convective outflow in the Waldo canyon fire. Mon. Wea. Rev., 142, 3061-3080, https://doi.org/10.1175/MWR-D-13-00361.1.

Johnson, W., and N. Kelley, 2000: Design specifications for the development of the initial validation software (version 3.0) for processing of NWTC 80-Meter Meteorological Tower Data. NREL Rep. TP-500-27104, 92 pp., https://doi.org/10.2172/752652.

Joint Fire Science Program, 2017: Validating mesoscale, atmospheric boundary prediction models and tools. JFSP Project Announcement FA-FON0017-0001, 13 pp., https://www.firescience.gov/AFPs/ 17-1-05/17-1-05_FON_Announcement.pdf.

Jorgensen, D. P., Z. Pu, P. O. Persson, and W. Tao, 2003: Variations associated with cores and gaps of a Pacific narrow cold frontal rainband. Mon. Wea. Rev., 131, 2705-2729, https://doi.org/ 10.1175/1520-0493(2003)131<2705:VAWCAG > 2.0.CO;2.

Kaimal, J. C., and J. E. Gaynor, 1983: The Boulder Atmospheric Observatory. J. Climate Appl. Meteor., 22, 863-880, https:// doi.org/10.1175/1520-0450(1983)022<0863:TBAO>2.0.CO;2.

Karels, J., and M. Dudley, 2013: Yarnell Hill Fire Serious Accident Investigation Report. Arizona State Forestry Division Rep., 116 pp. https://docs.google.com/file/d/0B36DIycSgbzWSUtjNkl1Z2ROT0k/ edit.

Keighton, S., J. Jackson, J. Guyer, and J. Peters, 2007: A preliminary analysis of severe quasi-linear mesoscale convective systems crossing the Appalachians. 22nd Conf. on Weather Analysis and Forecasting/18th Conf. on Numerical Weather Prediction, Park City, UT, Amer. Meteor. Soc., P2.18, http:// ams.confex.com/ams/pdfpapers/123614.pdf.
Kern, J., W. Jones, J. Murrian, and J. DiMaggio, 2004: Review of burnover incident at St. Sebastian River Preserve State Park, Indian River County, Florida, 24 February 2004. Florida Department of Environmental Protection Doc., 25 pp., http://www.wildfirelessons.net/HigherLogic/System/ DownloadDocumentFile.ashx?DocumentFileKey=83ebf8a11d12-001c-32b5-d279c795fa6b\&forceDialog $=1$.

Kishcha, P., and Coauthors, 2016: Modelling of a strong dust event in the complex terrain of the Dead Sea valley during the passage of a gust front. Tellus, $\mathbf{6 8 B}, 29751$, https://doi.org/ 10.3402/tellusb.v68.29751.

Koch, S. E., and C. A. Ray, 1997: Mesoanalysis of summertime convergence zones in central and eastern North Carolina. Wea. Forecasting, 12, 56-77, https://doi.org/10.1175/15200434(1997)012<0056:MOSCZI > 2.0.CO;2.

Kumer, V. M., J. Reuder, M. Dorninger, R. Zauner, and V. Grubišić, 2016: Turbulent kinetic energy estimates from profiling wind lidar measurements and their potential for wind energy applications. Renewable Energy, 99, 898-910, https://doi.org/10.1016/ j.renene.2016.07.014.

Kwon, D. K., and A. Kareem, 2009: Gust-front factor: New framework for wind load effects on structures. J. Struct. Eng., 135, 717-732, https://doi.org/10.1061/(ASCE)07339445(2009)135:6(717)

, - — , and K. Butler, 2012: Gust-front loading effects on wind turbine tower systems. J. Wind Eng. Ind. Aerodyn., 104-106, 109-115, https://doi.org/10.1016/j.jweia.2012.03.030.

Letchford, C. W., C. Mans, and M. T. Chay, 2002: Thunderstorms-Their importance in wind engineering (a case for the next generation wind tunnel). J. Wind Eng. Ind. Aerodyn., 90, 1415-1433, https://doi.org/10.1016/S0167-6105(02)00262-3.

Lombardo, F. T., D. A. Smith, J. L. Schroeder, and K. C. Mehta, 2014: Thunderstorm characteristics of importance to wind engineering. J. Wind Eng. Ind. Aerodyn., 125, 121-132, https:// doi.org/10.1016/j.jweia.2013.12.004

- M. S. Mason, and A. Z. de Alba, 2018: Investigation of a downburst loading event on a full-scale low-rise building. J. Wind Eng. Ind. Aerodyn., 182, 272-285, https://doi.org/ 10.1016/j.jweia.2018.09.020.

Lompar, M., M. Ćurić, and D. Romanic, 2018: Implementation of a gust front head collapse scheme in the WRF numerical model. Atmos. Res., 203, 231-245, https://doi.org/10.1016/ j.atmosres.2017.12.018.

Lu, N. Y., P. Hawbecker, S. Basu, and L. Manuel, 2019: On wind turbine loads during thunderstorm downbursts in contrasting atmospheric stability regimes. Energies, 12, 2773, https:// doi.org/10.3390/en12142773.

Lundquist, J. K., M. J. Churchfield, S. Lee, and A. Clifton, 2015: Quantifying error of lidar and sodar Doppler beam swinging measurements of wind turbine wakes using computational fluid dynamics. Atmos. Meas. Tech., 8, 907-920, https://doi.org/ 10.5194/amt-8-907-2015.

_, and Coauthors, 2017: Assessing state-of-the-art capabilities for probing the atmospheric boundary layer: The XPIA field campaign. Bull. Amer. Meteor. Soc., 98, 289-314, https:// doi.org/10.1175/BAMS-D-15-00151.1.

Mahoney, W. P., 1988: Gust front characteristics and the kinematics associated with interacting thunderstorm outflows. Mon. Wea. Rev., 116, 1474-1492, https://doi.org/10.1175/15200493(1988)116<1474:GFCATK > 2.0.CO;2.

Manwell, J. F., J. G. McGowan, and A. L. Rogers, 2002: Aerodynamics of wind turbines. Wind Energy Explained: Theory, Design and Application, John Wiley and Sons, 91-156. 
Martner, B. E., 1997: Vertical velocities in a thunderstorm gust front and outflow. J. Appl. Meteor., 36, 615-622, https://doi.org/10.1175/ 1520-0450(1997)036<0615:VVIATG > 2.0.CO;2.

McAnelly, R. L., and W. R. Cotton, 1986: Meso- $\beta$-scale characteristics of an episode of meso- $\alpha$-scale convective complexes. Mon. Wea. Rev., 114, 1740-1770, https://doi.org/10.1175/15200493(1986)114<1740:MSCOAE > 2.0.CO;2.

McCaffrey, K., and Coauthors, 2017: Identification of tower-wake distortions using sonic anemometer and lidar measurements. Atmos. Meas. Tech., 10, 393-407, https://doi.org/10.5194/amt-10-393-2017.

Moller, A. R., C. A. Doswell, M. P. Foster, and G. R. Woodall, 1994: The operational recognition of supercell thunderstorm environments and storm structures. Wea. Forecasting, 9, 327-347, https:// doi.org/10.1175/1520-0434(1994)009<0327:TOROST>2.0.CO;2.

Muñoz-Esparza, D., B. Kosović, P. A. Jiménez, and J. L. Coen, 2018: An accurate fire-spread algorithm in the Weather Research and Forecasting Model using the level-set method. J. Adv. Model. Earth Syst., 10, 908-926, https://doi.org/10.1002/2017MS001108.

Nguyen, H. H., L. Manuel, and P. S. Veers, 2011: Wind turbine loads during simulated thunderstorm microbursts. J. Renewable Sustain. Energy, 3, 053104, https://doi.org/10.1063/1.3646764.

O'Connor, A., and D. Kearney, 2019: Low level turbulence detection for airports. Int. J. Aviat. Aeronaut. Aerosp., 6, https:// doi.org/10.15394/ijaaa.2019.1302.

Paez, G., M. Strojnik, and M. K. Scholl, 2015: Analysis of propagation of complex fire: Case of the Yarnell Hill Fire 1. Proc. SPIE, 9608, 96081L, https://doi.org/10.1117/12.2191725.

Parker, M. D., and R. H. Johnson, 2000: Organizational modes of midlatitude mesoscale convective systems. Mon. Wea. Rev., 128, 3413-3436, https://doi.org/10.1175/1520-0493(2001) 129<3413:OMOMMC $>2.0$.CO;2.

— , and D. A. Ahijevych, 2007: Convective episodes in the eastcentral United States. Mon. Wea. Rev., 135, 3707-3727, https:// doi.org/10.1175/2007MWR2098.1.

Provod, M., J. H. Marsham, D. J. Parker, and C. E. Birch, 2016: A characterization of cold pools in the West African Sahel. Mon. Wea. Rev., 144, 1923-1934, https://doi.org/10.1175/MWR-D-15-0023.1.

Rauber, R. M., and S. L. Nesbitt, 2018: Radar Meteorology: A First Course. John Wiley and Sons, 488 pp.

Rhodes, M. E., and J. K. Lundquist, 2013: The effect of wind-turbine wakes on summertime US Midwest atmospheric wind profiles as observed with ground-based Doppler lidar. Bound.-Layer Meteor., 149, 85-103, https://doi.org/10.1007/s10546-013-9834-x.

Rosenkranz, P. W., 1998: Water vapor microwave continuum absorption: A comparison of measurements and models. Radio Sci., 33, 919-928, https://doi.org/10.1029/98RS01182.

Rotunno, R., J. B. Klemp, and M. L. Weisman, 1988: A theory for strong, long-lived squall lines. J. Atmos. Sci., 45, 463-485, https:// doi.org/10.1175/1520-0469(1988)045<0463:ATFSLL > 2.0.CO;2.

Roux, F., 1988: The West African squall line observed on 23 June 1981 during COPT 81: Kinematics and thermodynamics of the convective region. J. Atmos. Sci., 45, 406-426, https://doi.org/ 10.1175/1520-0469(1988)045<0406:TWASLO > 2.0.CO;2.

Sasaki, Y. K., and T. L. Baxter, 1986: The gust front. Thunderstorm Morphology and Dynamics, E. Kessler, Ed., University of Oklahoma Press, 187-196.

Sathe, A., J. Mann, J. Gottschall, and M. S. Courtney, 2011: Can wind lidars measure turbulence? J. Atmos. Oceanic Technol., 28, 853-868, https://doi.org/10.1175/JTECH-D-10-05004.1.

Schneider, D. G., 2009: The impact of terrain on three cases of tornadogenesis in the Great Tennessee Valley. Electron. J. Oper. Meteor., 10, 2009-EJ11, http://nwafiles.nwas.org/ej/ pdf/2009-EJ11.pdf.
Schumacher, R. S., and R. H. Johnson, 2006: Characteristics of U.S. extreme rain events during 1999-2003. Wea. Forecasting, 21, 69-85, https://doi.org/10.1175/WAF900.1.

Sharples, J. J., R. H. D. McRae, C. Simpson, P. Fox-Hughes, and C. Clements, 2017: Terrain-controlled airflows. Fire Manage. Today, 75, 20-24.

Simpson, J. E., 1969: A comparison between laboratory and atmospheric density currents. Quart. J. Roy. Meteor. Soc., 95, 758-765, https://doi.org/10.1002/qj.49709540609.

— spheric mesofront. Quart. J. Roy. Meteor. Soc., 106, 485-500, https://doi.org/10.1002/qj.49710644907.

Smith, B. T., R. L. Thompson, J. S. Grams, C. Broyles, and H. E. Brooks, 2012: Convective modes for significant severe thunderstorms in the contiguous United States. Part I: Storm classification and climatology. Wea. Forecasting, 27, 11141135, https://doi.org/10.1175/WAF-D-11-00115.1.

Solari, G., 2014: Emerging issues and new frameworks for wind loading on structures in mixed climates. Wind Struct., 19, 295 320, https://doi.org/10.12989/was.2014.19.3.295.

_ M. Burlando, P. De Gaetano, and M. P. Repetto, 2015: Characteristics of thunderstorms relevant to the wind loading of structures. Wind Struct., 20, 763-791, https://doi.org/10.12989/ was.2015.20.6.763.

Solheim, F., J. Godwin, and R. Ware, 1998a: Passive ground-based remote sensing of atmospheric temperature, water vapor, and cloud liquid water profiles by a frequency synthesized microwave radiometer. Meteor. Z., 7, 370-376, https://doi.org/ 10.1127/metz/7/1998/370.

, _ , E. R. Westwater, Y. Han, S. J. Keihm, K. Marsh, and R. Ware, 1998b: Radiometric profiling of temperature, water vapor and cloud liquid water using various inversion methods. Radio Sci., 33, 393-404, https://doi.org/10.1029/97RS03656.

Stull, R. B., 1988: An Introduction to Boundary Layer Meteorology. Kluwer Academic, 666 pp.

Tucker, D. F., and N. A. Crook, 1999: The generation of a mesoscale convective system from mountain convection. Mon. Wea. Rev., 127, 1259-1273, https://doi.org/10.1175/15200493(1999) $127<1259$ :TGOAMC > 2.0.CO;2.

Wakimoto, R. M., 1982: The life cycle of thunderstorm gust fronts as viewed with Doppler radar and rawinsonde data. Mon. Wea. Rev., 110, 1060-1082, https://doi.org/10.1175/15200493(1982) $110<1060$ :TLCOTG $>2.0$.CO;2.

Weisman, M. L., and J. B. Klemp, 1986: Characteristics of isolated convective storms. Mesoscale Meteorology and Forecasting, P. S. Ray, Ed., Amer. Meteor. Soc., 331-358.

Wilbanks, M. C., S. E. Yuter, S. P. de Szoeke, W. A. Brewer, M. A. Miller, A. M. Hall, and C. D. Burleyson, 2015: Near-surface density currents observed in the southeast Pacific stratocumulustopped marine boundary layer. Mon. Wea. Rev., 143, 3532-3555, https://doi.org/10.1175/MWR-D-14-00359.1.

Wilson, J. W., and W. E. Schreiber, 1986: Initiation of convective storms at radar-observed boundary-layer convergence lines. Mon. Wea. Rev., 114, 2516-2536, https://doi.org/10.1175/15200493(1986) $114<2516$ :IOCSAR $>2.0$. CO;2.

Wolfe, D. E., and R. J. Lataitis, 2018: Boulder Atmospheric Observatory: 1977-2016: The end of an era and lessons learned. Bull. Amer. Meteor. Soc., 99, 1345-1358, https:// doi.org/10.1175/BAMS-D-17-0054.1.

Zhang, S., G. Solari, P. De Gaetano, M. Burlando, and M. P. Repetto, 2018: A refined analysis of thunderstorm outflow characteristics relevant to the wind loading of structures. Probab. Eng. Mech., 54, 9-24, https://doi.org/10.1016/j.probengmech.2017.06.003. 